\title{
Renal Disease in Diabetes Mellitus: Recent Studies and Potential Therapies
}

Sameena Iqbal ${ }^{1 *}$ and Ahsan Alam ${ }^{2}$

${ }^{1}$ Department of Medicine, Division of Nephrology, Montreal General Hospital, Canada

${ }^{2}$ Department of Medicine, Division of Nephrology, Royal Victoria Hospital, Canada

\begin{abstract}
Diabetic kidney disease is the predominant cause of end stage kidney disease in North America, estimated to be 152 per million population in 2010. New guidelines published by KDIGO on Chronic Kidney Disease classification are discussed. In light of recent clinical trials, better insight has been gained on how improve management of diabetic patients to prevent renal disease and its progression, especially with regards to metabolic and blood pressure control. Unfortunately, studies of newer therapies such as endothelin 1 antagonists and bardoxolone methyl have been disappointing, but several other possible therapeutic agents are under investigation and may provide hope for patients with diabetes mellitus in the future.
\end{abstract}

Keywords: Diabetic nephropathy; Blood pressure targets; RAAS blockade; Intensive glycemic control

\section{Introduction}

Type 2 diabetes mellitus continues to rise in prevalence within North America and around the world. In 2010, the prevalence of diabetes mellitus was estimated to be $8.3 \%$ in the U.S [1]. In Canada, diabetes mellitus has risen from $5 \%$ in 2000 to $6.8 \%$ by 2008 [2]. There are likely several reasons accounting for the growth in type 2 diabetes in North America, but the predominant factors include an aging population, growing obesity rates, and shifts towards a sedentary lifestyle.

Diabetes among children and youth is also increasing. In Canada, children of age 0-9 have increased their incidence rates of type 1 diabetes, $0.1 \%$ or 3,726 cases between 1998 and 99 to $0.2 \%$ or 5,201 cases between 2008 and 2009 [2]. USA data also shows an increase in the incidence of type 1 diabetes, 19 per 10,000 population [1]. Possible causes that have been considered are genetic predisposition, vitamin $\mathrm{D}$ deficiency and absence of breast feeding [3].

Diabetic kidney disease is also the leading cause of end stage kidney disease in North America, estimated to be 152 per million population in 2010 [4], and accounts for $44 \%$ and $34 \%$ of incident cases in USA and Canada, respectively $[1,2]$. The significant socioeconomic burden imposed by diabetic nephropathy in the form of hospitalizations, cardiovascular disease, and mortality highlights the importance of identifying at-risk individuals and managing them aggressively.

Diabetic glomerulopathy can only be definitively diagnosed based on histology from a kidney biopsy. The clinical diagnosis of diabetic nephropathy requires a history of type 1 or type 2 diabetes mellitus along with elevated albuminuria and/or progressive kidney function (glomerular filtration rate) decline $[4,5]$.

\section{Chronic Kidney Disease in Diabetes: Kidney Disease Improving Global Outcomes (KDIGO) Guidelines}

The US National Kidney Foundation's 2002 guidelines (KDOQI) defined CKD for those with an estimated GFR (eGFR) less than $60 \mathrm{ml} /$ $\mathrm{min} / 1.73 \mathrm{~m}^{2}$ (stage 3-5) for more than 3 months duration, or a GFR greater that $60 \mathrm{ml} / \mathrm{min} / 1.73 \mathrm{~m}^{2}$ (stage 1-2) if there is evidence of kidney damage, such as albuminuria [6]. The international KDIGO guidelines updated this classification, now favouring the use of the CKD-Epi creatinine or cystatin C equation to estimate GFR. The eGFR categories have also been modified to recognize the difference in cardiovascular outcomes for $45-59 \mathrm{ml} / \mathrm{min} / 1.73 \mathrm{~m}^{2}$ (stage G3a) compared with 30-44 $\mathrm{ml} / \mathrm{min} / 1.73 \mathrm{~m}^{2}$ (stage G3b) [7] (Table 1).

KDIGO has also highlighted the importance of albuminuria, which is categorized as normal to near normal (A1), moderately elevated (A2), or severely elevated (A3) (Table 2) [7].Within every GFR category, albuminuria substantially increases the risk of ESRD, cardiovascular outcomes and all-cause mortality. Therefore albuminuria is now included in the GFR categories for the classification of CKD. The preferred measure of albuminuria isa spot Albumin-to-Creatine Ratio (ACR), followed by a spot Protein-to-Creatinine Ratio (PCR), automated urine protein reagent stick, or manual urine protein reagent stick [7]. The urine should ideally be an early morning urine sample. The terms microalbuminuria and macroalbuminuria are now discouraged, as they were mistakenly interpreted as being insignificantly small in quantity or qualitatively different than albuminuria. For this article we will only employ the terms 'microalbuminuria' and marcoalbuminuria,

\begin{tabular}{|c|c|c|}
\hline \multicolumn{3}{|c|}{ GFR Category GFR (ml/min/1.73m²) Terms } \\
\hline G1 & $\geq 90$ & Normal or High \\
\hline $\mathrm{G} 2$ & $60-89$ & Mildly decreased* \\
\hline G3a & $45-59$ & Mildly or moderately decreased \\
\hline G3b & $30-44$ & Moderately or severely decreased \\
\hline G4 & $15-29$ & Severely decreased \\
\hline G5 & $<15$ & Kidney failure \\
\hline
\end{tabular}

Abbreviations: CKD: Chronic Kidney Disease; GFR: Glomerular Filtration Rate ${ }^{*}$ Relative to young adult level

In the absence of evidence of kidney damage, neither GFR category G1 nor G2 fulfill the criteria for CKD

Reprinted by Permission from Nature Publishing Group, KDIGO 2012 Clinical Practice Guidelinefor the Evaluation and Management of Chronic Kidney Disease, Kidney International supplement 3: 27, table 5, Copyright (2013)

Table 1: Categories of GFR: addition of G3a and G3b.

*Corresponding author: Sameena Iqbal, Department of Medicine, Montreal General Hospital, Division of Nephrology, 1650 Cedar Ave, L4-512, Montreal, Quebec Canada, Tel: 514-934-1934; Fax: 514-934-8248; E-mail: sameena.iqbal@mcgill.ca Received March 13, 2013; Accepted May 22, 2013; Published May 28, 2013

Citation: Iqbal S, Alam A (2013) Renal Disease in Diabetes Mellitus: Recent Studies and Potential Therapies. J Diabetes Metab S9: 006. doi:10.4172/2155 6156.S9-006

Copyright: (c) 2013 lqbal S, et al. This is an open-access article distributed under the terms of the Creative Commons Attribution License, which permits unrestricted use, distribution, and reproduction in any medium, provided the original author and source are credited. 


\begin{tabular}{|c|c|c|c|c|}
\hline \multicolumn{5}{|c|}{ ACR (approximate equivalent) } \\
\hline Category & $\begin{array}{c}\text { AER (mg/24 } \\
\text { hours) }\end{array}$ & $\mathbf{( m g / m m o l )}$ & $\mathbf{( m g / g )}$ & Terms \\
\hline A1 & $<30$ & $<3$ & $<30$ & Normal to mildly increased \\
\hline A2 & $30-300$ & $3-30$ & $30-300$ & Moderately increased \\
\hline A3 & $>300$ & $>30$ & $>300$ & Severely Increased ${ }^{* *}$ \\
\hline
\end{tabular}

Abbreviations: AER: Albumin Excretion Rate; ACR: Albumin-to-Creatine Ratio; CKD: Chronic Kidney Disease

${ }^{*}$ Relative to young adult level

**Including nephrotic Syndrome (albumin excretion usually $>2200 \mathrm{mg} / 24$ hours [ACR $>2200 \mathrm{mg} / \mathrm{g} ;>220 \mathrm{mg} / \mathrm{mmol}$ ])

Reprinted by Permission from Nature Publishing Group, KDIGO 2012 Clinical Practice Guidelinefor the Evaluation and Management of Chronic Kidney Disease, Kidney International supplement 3: 28, table 6, Copyright (2013)

Table 2: Albuminuria Categories in CKD.

instead of moderately (A2) or severely increased albuminuria (A3), when citing results from studies that used the older terminology.

\section{Prevalence of Moderately or Severely Increased Albuminuria in Diabetes}

In type 1 diabetes, moderate albuminuria was more prevalent in the studies prior to 1990, ranging from 9-22\% [8]. Viberti et al. reported microalbuminuria (A2) in $12.6 \%$ of the 87 type 1 diabetics, from whom $88 \%$ progressed to severe albuminuria when followed for 14 years [9]. Similar progression rates from microalbuminuria (A2) to macroalbuminuria (A3) by Mogensen and Christensen reported among 43 studied 1969-1976 and re-evaluated in 1983 [10].

Over time, the prevalence of severe albuminuria has decreased [8]. Hovind et al. reported a decline in prevalence of proteinuria from $1965-1969$ to $1979-1984,31.2 \%$ and $13.7 \%$ respectively [11]. In 2004, Nordwall et al. also published similar results (Table 3) [12].

Interestingly, moderate albuminuria does not mean the individual with type 1 diabetes is destined to progress to severe albuminuria. Regression to normoalbuminuria (A1) has been noted in association with good metabolic and BP control [13]. The EDIC trial found a regression of albuminuria in $40 \%$, despite ACE inhibitors and Angiotensin II receptor blockers only making up a quarter of the antihypertensive medications in the study [14].

In type 2 diabetes, the prevalence of moderate albuminuria is higher than in type 1 . The prevalence of moderate albuminuria ranges between 21-39\% (Table 4) [22-28]. Severe albuminuria has been reported to occur in 3.0-20.5\% [22-28]. The prevalence of albuminuria has not changed over time but certainly differs across ethnic groups. Aboriginals, Asians and Hispanics demonstrate higher prevalences of proteinuria than Caucasians [29].

\section{Cardiovascular Risk of Diabetic Renal Disease and Albuminuria}

Even in $\mathrm{DM}$, albuminuria and CKD are important predictors of cardiovascular mortality. The Finnish Diabetic Nephropathy study showed that in 4201 type 1 DM adults followed over a median of 7 years, those who were normoalbuminuric had a similar mortality risk as the general population [30]. However, compared to normoalbuminuria those with microalbuminuria (moderate albuminuria), macroalbuminuria (severe albuminuria) and ESRD had increased standardized mortality hazard ratios (HR) of 2.8, 9.2 and 18.3 , respectively. A GFR below $60 \mathrm{ml} / \mathrm{min} / 1.73 \mathrm{~m}^{2}$ also was associated with an increased adjusted HR of 1.7 (95\% CI 1.1-2.6) compared to a
GFR of $60-90 \mathrm{ml} / \mathrm{min} / 1.73 \mathrm{~m}^{2}$ [30]. The most common cause of death was cardiovascular mortality (about $50 \%$ of all deaths).

Similarly, an Austrian cohort of 648 subjects with type $1 \mathrm{DM}$ followed for 20 years found that microalbuminuria (A2) and macroalbuminuria (A3) were associated with 2- and 4- fold increase in mortality compared to normoalbuminuria at baseline [31]. Astrup et al. compared cardiovascular events and mortality in 199 types $1 \mathrm{DM}$ with nephropathy to 192 with normoalbuminuria followed for ten years [32]. Fatal and nonfatal cardiovascular events occurred in $40 \%$ of the nephropathy group and $10 \%$ in the normoalbuminuric group. Similarly, all-cause mortality, the majority cardiovascular, was much higher in the nephropathy group, $30 \%$ vs. $8 \%$ [32].

Among 3228 subjects from the combined IDNT and RENAAL trial data, incident ESRD, cardiovascular events, and mortality rates were 7.1, 2.9 and 4.6 per 100 person years [33]. The risk was highest if the eGFR was less than $30 \mathrm{ml} / \mathrm{min} / 1.73 \mathrm{~m}^{2}$ and ACR was more than $2 \mathrm{mg} / \mathrm{g}$ [33].

An Italian cohort of 1538 type $2 \mathrm{DM}$ patients were followed for 11years to assess the relationship of GFR, albuminuria and mortality [34]. Albuminuria $(>200 \mu \mathrm{g} / \mathrm{min})$ had a 2-fold increase in all cause and cardiovascular mortality compared to normoalbuminuria. GFR less than $60 \mathrm{ml} / \mathrm{min} / 1.73 \mathrm{~m}^{2}$ showed an adjusted HR 1.23 (95\% CI 1.03-1.47) for all-cause mortality and 1.18 (95\% CI 0.92-1.52) for cardiovascular mortality [34].

The incorporation of albuminuria in the CKD classification by KDIGO was an important change, and strongly influenced by the consistent interaction of albuminuria on cardiovascular mortality.

\section{Genetics}

Nephropathy in type $2 \mathrm{DM}$ is more likely to occur if the individual has a relative with diabetic nephropathy. If one parent has diabetic nephropathy, the prevalence of proteinuria is $14 \%$ among their offspring [35]. This risk increases further if both parents have nephropathy. Similar risks were noted in DCCT for relatives with type 1 diabetic kidney disease [36].

Diabetic renal disease is a complex genetic trait and cannot be attributed to a monogenic mutation. Genome wide association and linkage studies have identified several loci associated with renal disease in diabetes, including 3q,7q, 10p, 14q, and 18q [37]. As an example, the candidate gene ELMO-1 was associated with diabetic nephropathy in Caucasians (type 1), African American (type 2) and Japanese populations [38]. In the DCCT/EDIC cohort, chromosomal regions 9q and $11 \mathrm{p}$ were significant, but were not validated in Japanese with type 2 diabetic nephropathy [39]. A great deal more work will have to be done to identify all potential genetic polymorphisms and validate these findings in different populations.

\section{Histopathology}

The typical histopathological changes noted in diabetic nephropathy include glomerular basement membrane thickness, mesangial expansion, podocyte foot processes effacement, and afferent and efferent arteriolar hyalinosis [40]. These findings are not consistently seen in type 2 diabetes mellitus.

A recent classification for diabetic nephropathy has been published by Tervaert et al. which was created by consensus of international experts [41]. They combined type 1 and type 2 DM for development of this classification. The pathology is classified into 4 groups, class 1: mild 
Citation: Iqbal S, Alam A (2013) Renal Disease in Diabetes Mellitus: Recent Studies and Potential Therapies. J Diabetes Metab S9: 006. doi:10.4172/2155-6156.S9-006

Page 3 of 16

\begin{tabular}{|c|c|c|c|c|c|c|c|c|}
\hline & $\mathbf{N}$ & Population & $\begin{array}{l}\text { Years of } \\
\text { follow up }\end{array}$ & $\begin{array}{c}\text { Moderately } \\
\text { increase } \\
\text { Albuminuria (A2) }\end{array}$ & $\begin{array}{c}\text { Severely } \\
\text { increased } \\
\text { albuminuria (A3) }\end{array}$ & $\begin{array}{l}\text { Progression A2 } \\
\text { to A3 }\end{array}$ & CKD & $\begin{array}{c}\text { Regression } \\
\text { to A1 }\end{array}$ \\
\hline Viberti et al. 1982 [9] & 63 & $\begin{array}{l}\text { Insulin dependent } \\
\text { DM }\end{array}$ & 14 & $12.6 \%$ & $14 \%$ & $88 \%$ & & \\
\hline Andersen 1983 [17] & 1303 & Type 1 DM & 25 & & $41 \%$ & & $41 \%$ & \\
\hline $\begin{array}{l}\text { Mogensen and Christensen } \\
1984 \text { [10] }\end{array}$ & 43 & $\begin{array}{l}\text { type 1DM } \\
(\mathrm{A} 1, \mathrm{~A} 2)\end{array}$ & $\begin{array}{l}1969-1976 \\
\text { and } 1983\end{array}$ & $32 \%$ & $28 \%$ & $86 \%$ & & \\
\hline $\begin{array}{l}\text { Mathiesen } \\
1984 \text { [15] }\end{array}$ & $\begin{array}{l}227 \\
71\end{array}$ & $\begin{array}{l}\text { type } 1 \mathrm{DM} \\
(\mathrm{A} 1, \mathrm{~A} 2)\end{array}$ & 6 & $22.5 \%$ & $4 \%$ & $14 \%$ & & \\
\hline $\begin{array}{l}\text { Borch-Johnsen } \\
1985 \text { [18] }\end{array}$ & 1030 & Type 1 DM & $\begin{array}{l}\text { 1933-1952 } \\
\text { To } 1982\end{array}$ & & $39 \%$ & & & \\
\hline Parving 1988 [16] & 982 & $\begin{array}{l}\text { Age less than } \\
41 \text { with insulin } \\
\text { dependent DM }\end{array}$ & $\begin{array}{l}\text { Cross- } \\
\text { sectional }\end{array}$ & $22 \%$ & $18 \%$ & & & \\
\hline $\begin{array}{l}\text { Hovind } \\
2003 \text { [11] }\end{array}$ & 600 & Type 1 DM & $\begin{array}{l}1965-1984 \text { to } \\
2000\end{array}$ & & $\begin{array}{l}31.1(1965-69) \text { to } \\
13.7 \%(1979-84)\end{array}$ & & & \\
\hline $\begin{array}{l}\text { Perkins } \\
2003[21]\end{array}$ & 386 & Type 1 DM (A2) & 6 & $45 \%$ & $15 \%$ & & & $50 \%$ \\
\hline $\begin{array}{l}\text { Nordwall } \\
2004[12]\end{array}$ & 269 & $\begin{array}{l}\text { Type } 1 \text { DM from } \\
\text { childhood }\end{array}$ & $1961-1985$ & & $\begin{array}{l}30 \%(1961-65) \\
\text { to } 13 \%(1971-75)\end{array}$ & & & \\
\hline $\begin{array}{l}\text { Steinke } \\
2005[19]\end{array}$ & 170 & $\begin{array}{l}\text { type } 1 \mathrm{DM} \\
\text { (A1) }\end{array}$ & 5 & $4.7 \%$ & & & & $64 \%$ \\
\hline Zerbini 2006 [20] & 146 & Type 1 DM (A1) & 4 & $18.5 \%$ & & & & \\
\hline $\begin{array}{l}\text { De Boer } \\
2011[14]\end{array}$ & 1441 & Type 1 DM (A2) & 13 & $22.5 \%$ & $28 \%$ & & $15 \%$ & $40 \%$ \\
\hline
\end{tabular}

Table 3: Prevalence of Albuminuria, progression and regression in type $1 \mathrm{DM}$.

\begin{tabular}{|c|c|c|c|c|c|c|c|}
\hline Type 2 DM & $\mathbf{n}$ & Years of follow up & Population & Microalbuminuria (A2) & Macroalbuminuria (A3) & CKD & Normoalbuminuria (A1) \\
\hline $\begin{array}{l}\text { Valmadrid } \\
2000[22]\end{array}$ & 840 & & $\begin{array}{c}\text { Population study of } \\
\text { type } 2 \text { DM }\end{array}$ & $24.8 \%$ & $20.5 \%$ & & \\
\hline Gerstein 2001 [23] & 3498 & 4.5 & $\begin{array}{c}\text { Age over } 55 \text { with } \\
\text { history of CV disease } \\
\text { (including DM) }\end{array}$ & $32.6 \%$ & & & \\
\hline $\begin{array}{l}\text { Kramer } \\
2003 \text { [24] }\end{array}$ & 1197 & Cross-sectional & $\begin{array}{c}\text { NHANES III: DM } \\
\text { type } 2\end{array}$ & $32 \%$ & $5 \%$ & $13 \%$ & $30 \%$ \\
\hline Tapp 2004 [25] & 11247 & Cross-sectional & $\begin{array}{c}\text { Australian population- } \\
\text { based study }\end{array}$ & $21 \%$ & $4.3 \%$ & & \\
\hline $\begin{array}{l}\text { Meisinger } \\
2008 \text { [26] }\end{array}$ & 581 & Cross-sectional & $\begin{array}{l}\text { KOA Augsburg } \\
\text { Diabetes Family } \\
\text { Study }\end{array}$ & $27.2 \%$ & $9 \%$ & & \\
\hline \begin{tabular}{|l} 
Jia \\
2009 [27]
\end{tabular} & 3714 & Cross-sectional & $\begin{array}{l}\text { Shanghai diabetic } \\
\text { complications study }\end{array}$ & $22.8 \%$ & $3 \%$ & $29.6 \%$ & \\
\hline $\begin{array}{l}\text { Dwyer } \\
2011 \text { [28] }\end{array}$ & 11527 & Cross-sectional & DEMAND & $39 \%$ & $9.8 \%$ & $22 \%$ & $17 \%$ \\
\hline
\end{tabular}

Table 4: Prevalence of Albuminuria, Normoalbuminuria, and CKD in type 2 DM.

changes on light microscopy with electron microscopy evidence of glomerular basement thickening, class IIa: mild mesangial expansion, class IIb: severe mesangial expansion, Class III: nodular sclerosis with at least one Kimmelstiel-Wilson lesion, and class IV advanced glomerulosclerosis with more than $50 \%$ of the glomeruli showing global glomerulosclerosis [41]. The authors score separately the interstitial, vascular and non-diabetic glomerular lesions. This classification is the first to try to have studies report the pathology in diabetic renal disease in the same manner.

Combining the type 1 and type 2 DM pathology has it shortcomings. Type $2 \mathrm{DM}$ progression of renal disease is different from type 1 diabetic nephropathy [42]. In type $1 \mathrm{DM}$, the early findings include glomerular basement membrane thickening, mesangial expansion with afferent and efferent arteriolar hyalinosis. Large vessel arteriosclerosis, tubulointerstitial inflammation and focal and global glomerulosclerosis tend to occur later in the disease course. Najafian and Mauer have reported glomerular tubular junction abnormalities (GTJA) that are late features of diabetic nephropathy [43]. These are described as atrophic tubules (subdivided into short atrophic tubules, long atrophic tubules and atrophic tubules with no observable glomerular opening) [43]. GTJA was associated with the tip lesion seen in FSGS and decline in GFR. The histopathology usually correlates well with the clinical progression of type $1 \mathrm{DM}$ renal disease [43].

However, in type $2 \mathrm{DM}$, the renal biopsy literature is biased, because most studies report the results of biopsies performed in a setting where the subjects had clinical presentations that were uncharacteristic for diabetic nephropathy [44]. This selection bias permits over estimation of non-diabetic renal disease in the diabetic population. Several studies 
have shown a high prevalence of non-diabetic glomerular disease in cases with proteinuria and type 2 diabetes mellitus, reported 12 to $53 \%[45,46]$. Table 5 describes the non-diabetic renal disease found in these reports. Type 2 DM Patients with albuminuria may have near normal renal pathology, yet over a third may have signs of hypertensive nephrosclerosis or tubulointerstitial disease [42].

Decrease of GFR is associated with glomerular basement membrane thickening and mesangial expansion [54]. Mesangial expansion is an important glomerular change that results in decrease renal function. The glomerular changes may not be as advanced with albuminuria as in type 1 diabetes. Particularly, type 2 diabetic subjects without retinopathy are more likely to have albuminuria related to non-diabetic renal disease [55]. Thus the decline in GFR and albuminuria do correlate with the structural changes of diabetic nephropathy seen on histopathology, such as glomerular basement thickening and mesangial expansion but not as strongly as in type 1 diabetes [56]. In fact Okada et al. applied Taevert's classification in a study of 69 patients with type 2 diabetes found the interstitial fibrosis was a strong predictor of renal end points, not the glomerular changes [57].

\section{Progression of Renal Disease in Type 1 Diabetes Mellitus}

The traditional pattern of renal progression in diabetic kidney disease often begins with glomerular hyperfiltration, leading to microalbuminuria, followed by overt proteinuria, and finally GFR decline. Elevated albuminuria is thus used in the definition of diabetic nephropathy, yet renal function can decrease even before elevated albuminuria is detected as noted in type 1 diabetes mellitus [20]. There has been increased regression of proteinuria with the introduction of ACE inhibition and ARB; however, ESRD rates have not declined [58,59]. Rosolowsky et al. showed that between 1991-1995, 1996-2000, 2001-2004, the incident rates for ESRD were 5.3, 5.5, 6.8 cases per 100 person years [58]. Similar results were found by Forsblom et al. with rate of ESRD at 5.1 cases per 100 person years [59]. The incident rates have remained the same, indicating delay or slowing of renal progression, but not complete cessation of the process.

Individuals may progress from moderate levels of albuminuria to CKD without developing severe levels of albuminuria. About half the patients who developed new onset microalbuminuria did not progress to proteinuria even though GFR declined significantly [56]. Cosatcou et al. showed similar findings of those subjects who had a GFR decline, $26 \%$ did not increase in albuminuria [60]. ACE inhibition was not used in these subjects, so RAAS blockade was not an explanation [60]. Misclassification of individuals with normal renal function labelled to have CKD because of the inaccuracies of estimated GFR equations may explain some of the GFR decline in stable albuminuric patients.
Improvement in glycemic control alone may explain the decrease in albuminuria. Other non-diabetic causes for renal injury caused by NSAIDs, radiocontrast dye, ATN and AIN may contribute to the decline of GFR but no worsening in albuminuria [60].

\section{Progression of Renal Disease in Type 2 Diabetes Mellitus}

Diabetic nephropathy progresses from normoalbuminuria to microalbuminuria (A2) then to macroalbuminuria (A3) at the rate of $2.0 \%, 2.8 \%, 2.3 \%$ per year [61]. Since patients with type 2 diabetes mellitus often have multiple comorbidities including obesity and hypertension, renal disease may be present far before the first presentation to a physician. Therefore, chronic kidney disease maybe present even at the time of diagnosis of diabetes mellitus, about $7 \%$ in data from UKPDS [62].

Data from the National Health and Nutrition Examination Survey (NHANES) have demonstrated that only $65 \%$ of diabetics with low kidney function have micro albuminuria $(>30 \mathrm{mg} /$ day of albumin excretion) Furthermore, studies have demonstrated that even diabetic nephropathy can progress without development of incident proteinuria [63-65]. Population data from NHANES III (population estimate 1.1 million), as well as cohort analyses from the NEFRON $(\mathrm{N}=3,893)$ and AusDiab $(\mathrm{N}=11,247)$ studies have established that $30-55 \%$ of type 2 diabetics with CKD $\left(\right.$ GFR $\left.<60 \mathrm{ml} / \mathrm{min} / 1.73 \mathrm{~m}^{2}\right)$ are normoalbuminuric $[66,67]$. The increased recognition of non-proteinuric diabetic chronic kidney disease may in part be due to more successful glycemic, lipid, and BP control. Data from the UKPDS, for example, show that HbAlc reduction is associated with reduced albuminuria, but not improved GFR [68].

Since escalating albuminuria may not be reliable as a predictor for GFR decline, better diabetic nephropathy markers are needed. Neutrophil Gelatinase-Associated Lipocalin (NGAL), Kidney injury molecule 1 (KIM1) and Liver-Type Fatty Acid-Binding Protein (LFABP) have emerged as possible markers [69]. Urine Proteomics has recently facilitated Zürbig et al. to create a panel of urinary peptides to predict CKD progression [70]. They examined the urinary proteome of diabetic patients with normoalbuminuria, low/moderate albuminuria, and diabetic nephropathy. Reduced quantities of several collagen fragments were present in diabetic individuals, as compared to healthy controls. The urinary proteome was also able to differentiate diabetic patients with those having other chronic kidney diseases. The next stage is to assess whether the urine proteomics identify the subjects who are at risk of diabetic nephropathy and an intervention prevents progression of the disease. Such a study has been started, named Priority in Europe [71].

\begin{tabular}{|c|c|c|c|c|c|c|c|c|c|}
\hline & $\mathbf{n}$ & Diabetic features & Glomerulosclerosis & Membranous & FSGS & Minimal change & GN & $\lg A$ & AIN/ATN \\
\hline $\begin{array}{l}\text { Fiorettoet al. } \\
1996 \text { [47] }\end{array}$ & 34 & $30 \%$ A2 50\% A3 & $35 \%$ & & & & & & \\
\hline Wirta et al. 2000 [48] & 166 & $82 \%$ & & $3 \%$ & $4 \%$ & & $2.4 \%$ & & \\
\hline Tone et al. 2005 [53] & 97 & $52 \%$ & $3.2 \%$ & $6.5 \%$ & $8.1 \%$ & $12.9 \%$ & $10.3 \%$ & $25.8 \%$ & \\
\hline $\begin{array}{l}\text { Huang et al. } \\
2007 \text { [51] }\end{array}$ & 52 & $61.5 \%$ & $4 \%$ & $2 \%$ & $6 \%$ & $8 \%$ & $15 \%$ & $6 \%$ & $6 \%$ \\
\hline Lin et al. 2009 [52] & 50 & $78 \%$ & $4 \%$ & $2 \%$ & & $4 \%$ & $4 \%$ & $12 \%$ & $8 \%$ \\
\hline $\begin{array}{l}\text { Mou et al. } \\
2010 \text { [50] }\end{array}$ & 69 & $47.8 \%$ & $11.6 \%$ & $8.7 \%$ & $37.7 \%$ & $15.9 \%$ & $10.1 \%$ & $15.9 \%$ & \\
\hline $\begin{array}{l}\text { Chang et al. } \\
2011 \text { [49] }\end{array}$ & 152 & $46 \%$ & & $33 \%$ & $12 \%$ & $16 \%$ & $9.2 \%$ & $12 \%$ & $5 \%$ \\
\hline
\end{tabular}

Table 5: Renal biopsies and renal pathology in the diabetic population. 


\section{Trajectories of Diabetic Nephropathy}

One hundred and sixty one patients with type 1 diabetes and albuminuria were studied at the Joslin Diabetes Centre, measuring eGFR with CKD-Epi formula [72]. The GFR trajectories varied, from stable (less than $3.5 \mathrm{ml} / \mathrm{min} / 1.73 \mathrm{~m}^{2}$ per year) in one third of the subjects, to a linear decline in $30 \%$, and non-linear decline in the remaining. The median decline in GFR was $-2.9 \mathrm{ml} / \mathrm{min} / 1.73 \mathrm{~m}^{2}$ per year $(-7.1$ to -1.27 $\mathrm{ml} / \mathrm{min} / 1.73 \mathrm{~m}^{2}$ per year) [72].

Two other studies have shown that the decline in renal function in type 1 diabetes with normoalbuminuria is less frequent and not as fast as with albuminuria $[56,73]$. However, early decline in GFR occurs with the appearance of microalbuminuria (moderate albuminuria). In the Oxford Regional Prospective study, 102 type 1 diabetics were followed with serum creatinine measurements. GFR decreased by mean of $3.4 \mathrm{ml} / \mathrm{min} / 1.73$ $\mathrm{m}^{2} /$ year and was associated with a rise in albuminuria [73]. Perkins and Krolewski reported in normoalbuminuric subjects a 9\% decline in GFR per year compare to $31 \%$ GFR decline per year in those with albuminuria, with a follow-up of 8-12 years of subjects with GFR that was normal at baseline, though the group included cases of hyperfiltration [56].

In type $2 \mathrm{DM}$, non-diabetic low to moderate levels of albuminuria is often present with a slower rate of decline in renal function than diabetic nephropathy with albuminuria or other non-diabetic glomerular disease [74]. The lower urinary albumin excretion may indicate atherosclerosis or glomerular ischemia associated with endothelial dysfunction. On the other hand, microalbuminuria (A2) that progresses to macroalbuminuria (A3) and then CKD is more consistent with the natural history of diabetic nephropathy.

Non-diabetic glomerular disease is seen among those with diabetes, especially in association with the following clinical features: no retinopathy, microscopic hematuria, or nephrotic-range proteinuria greater than 5 grams per day [75].

Diabetes mellitus type 2 may not follow the natural history noted above due to non-diabetic glomerular diseases contributing to renal function. The mean annual GFR decline noted in 2 studies was 1.3$3 \mathrm{ml} / \mathrm{min} / 1.73 \mathrm{~m}^{2}$ for microalbuminuric individuals and $2.8-5.0 \mathrm{ml} /$ $\min / 1.73 \mathrm{~m}^{2}$ among those with macroalbuminuria [76,77]. In the Pima Indians, the degree of albuminuria and early decline in renal function i.e. GFR greater than $3.3 \%$ per year in the first four years, predict the development of ESRD [78].

GFR decline is occurring both in type 1 and type 2 DM, with increase rate of decline in the presence of albuminuria when compared to normoalbuminuria.

\section{Metabolic Factors}

\section{Pathways of pathogenesis of diabetic nephropathy}

Several pathways have been identified that initiate and potentiate the progression of diabetic kidney disease. The common pathways are summarized below.

Oxidative stress: mitochondrial ROS is induced by hyperglycemia. Glucose is metabolized through the polyol pathway, leading to a decrease in the amount of NADPH which in turn lowers the availability of glutathione. With less glutathione, reactive oxidative species will further increase intracellularly [79].

PKC: High intracellular glucose levels increase diacylglycerol, which stimulates Protein Kinase C activity [80]. PKC has an important role in increasing extracellular matrix production through the pathway of TGF beta. PKC beta is associated with mesangial expansion and renal hypertrophy [80].

AGE: Advanced glycation end products are compounds produced through non enzymatic glycosylation of certain proteins in the setting of excess glucose. These compounds accumulate in glomerular epithelial cells and changes permeability of the GBM [81]. Further stimulation of cytokines and TGF beta occurs due to activation of the receptor for AGEs. RAGEs also participate in the transformation of tubular cells to myofibroblasts, which induce tubulointerstitial fibrosis [81].

RAAS: Hyperglycemia is associated with elevated Ang II levels. Ang II stimulates certain cytokines, such as TGF beta and VEGF, chemokines, MCP-1 and growth hormones [82]. These substances further exacerbate the tubulointerstitial renal disease.

\section{Glomerular Hemodynamic Factors}

Glomerular hyperfiltration is seen more often in type 1 rather than type $2 \mathrm{DM}$, and occurs with increase extracellular volume, increased glomerular capillary pressures with renovascular vasodilation. Usually renal hypertrophy will coincide with hyperfiltration, which occurs due to hyperglycemia. Hyperglycemia induces systemic hormones to further stimulate the release IGF-1, which is a growth factor [83]. TGF beta is also increased in levels in the setting of hyperglycemia and high Ang II levels. Subsequently, TGF beta stimulates proximal tubule cell growth [83]. Other factors implicated in renal hypertrophy are VEGF, Protein Kinase C and reduction in AMP protein kinase [83].

Not any of these processes are occurring in isolation in diabetes. Therefore, in the future, therapies for diabetic kidney disease will be targeting multiple sites to ameliorate the disease.

\section{Management}

\section{Glycemic control: Type 1 DM}

In 1993, the DCCT trial was a landmark randomized clinical trial that studied the effects of intensive glycemic control with an external insulin pump compared to two injections a day in the conventional care group [84]. The target $\mathrm{HbAlc}$ was $6.05 \%$ in the intensive glycemic control group. The study recruited 1441 subjects, and followed them for mean 6.5 years. Microalbuminuria (A2) was reduced by $34 \%$ in the intensive group compared to the conventional arm in the primary prevention cohort and by $43 \%$ in the secondary prevention cohort [84]. Albuminuria (A3) was reduced by $56 \%$ in the intensive group compared to conventional therapy [84].

Combined macrovascular events of cardiovascular and peripheral vascular disease were reduced in the intensive group by $41 \%$ but were not found to be statistically significant [84].

Those who were enrolled and completed the DCCT were then followed as a prospective cohort (EDIC) [85]. The combined mean follow up period was 22years. 1222 had serum creatinine values to assess CKD (impaired renal function of eGFR below $60 \mathrm{ml} / \mathrm{min} / 1.73$ $\mathrm{m}^{2}$ ) [85]. CKD was reduced by $50 \%$ in the intensive group when compared to conventional treatment. The annual decline of eGFR was less in the intensive group compared to the conventional. When CKD and death were combined, the intensive therapy group had a reduction risk of $37 \%$ that was statistically significant [85].

Intensive glycemic control lowers development of albuminuria and decline in GFR. There is a "metabolic memory", the renal and vascular tissues are susceptible to long term effects created by the environment of glycemia early in the disease [86]. 
Another method to normalize glucose levels in type $1 \mathrm{DM}$ is pancreas transplantation. Fioretto and Mauer biopsied native kidneys in 13 patients who received a pancreas transplantation alone and found at 5 years to have stable lesions of diabetic nephropathy, particularly glomerular basement membrance thickness and mesangial matrix [87]. But when these individuals were biopsied at 10 years post pancreas transplant, these lesions had regressed. GBM and TBM thickness normalized and total mesangial matrix volume decreased at 10 years [87]. At the same time, the tubulointerstitial fibrotic changes seen at 5 years, and attributed to cyclosporine therapy, had improved by 10 years.

It is hypothesized that the metabolic memory from the elevated glucose levels prior to transplant must take a long time to recognize a normoglycemic environment [87].

Patients must be chosen appropriately for pancreas transplantation alone because 2 small studies have shown worsening renal function post transplant $[88,89]$. One found age, gender, preoperative eGFR and duration of diabetes factors associated with decline in renal function [88]. Many perioperative factors can facilitate renal function decline, such as medications, AKI, infections and volume management [88].

\section{Glycemic control: Type 2 DM}

UKPDS study showed more intensive blood glucose control with median $\mathrm{HbAlc}$ of $7.4 \%$ compared to the liberal control of $8.0 \%$ reduced the relative risk of developing microalbuminuria or worsening of albuminuria by $33 \%[60,90]$. The relative risk of all microvascular complications was lowered by $25 \%$ as well.

In the ACCORD study 10251 type 2 diabetes mellitus subjects were randomized to $\mathrm{HbAlc}$ of $6.4 \%$ (intensive control) versus $7.5 \%$ (standard control) $[61,91]$. The study terminated early at 3.6 years due to higher mortality rates in the intensive control group, HR 1.22 (95\% CI 1.011.46). The intensive control subjects had more episodes of significant hypoglycemia and weight gain. After 5 years, the data published shows a $25 \%$ reduction in incident microalbuminuria, consistent with the findings of ADVANCE and VADT. The increase risk of mortality with intensive therapy was postulated to be due to several possibilities, including the increased use of medications of different classes (1-2 medications with insulin), higher use of insulin and possible weight gain as a result of insulin to lower Hbalc and/or the drug combinations/ interactions were contributing to this difference [91].

In ADVANCE, tight glycemic control, median $6.5 \%$ versus standard of $7.3 \%$, resulted in a $21 \%$ reduction in new and worsening nephropathy [92].

VADT also followed over 500 subjects with type 2 diabetes and found intensive glycemic control (6.9\%) versus $8.4 \%$ [93]. No difference in macrovascular outcome was found. A minor benefit in worsening of albuminuria was noted in the intensive glycemic control group.

These three large RCTs looking at cardiovascular mortality and intense glycemic therapy did not show any benefit and possibly harm. Although about a $20 \%$ reduction in albuminuria occurs with intense glycemic control, this was counterbalanced by an increased risk of serious hypoglycemia and possibly higher mortality. Therefore intensive control should be offered to a select group that senses hypoglycemic events and has minimal cardiovascular risk.

Several guidelines suggest targeting a $\mathrm{HbA1c}$ about $7 \%$ in both type 1 and type 2 diabetes, but that physicians should tailor glycemic control to each individual patient [7,94]. Canadian Diabetes Association recommends aiming for a $\mathrm{HbA1c}$ below $7 \%$ in type $2 \mathrm{DM}$ that have minimal hypoglycemic events, and higher than 7\%in those with significant burden of comorbidity or decreased in life expectancy.

\section{Primary Prevention}

\section{Type 1 DM}

Normotensive: Mauer et al. published a landmark study assessing the effects of ACE inhibitor, $\mathrm{ARB}$ and placebo on the progression of renal disease in type $1 \mathrm{DM}$ among 256 subjects, with renal biopsy data [95]. Interestingly, no benefit was found by ACE inhibitor or ARB treatment in the progression of diabetic nephropathy. The DIRECT investigators pooled their studies looking at the effects of candesartan on the retinopathy development and progression [96]. They found that new onset microalbuminuria was not decreased with ARB treatment compared to placebo. The study population had low cardiovascular risk as they had normal BP or controlled hypertension. Therefore, it is not recommended to treat type $1 \mathrm{DM}$ with $\mathrm{ACE}$ inhibition or $\mathrm{ARB}$ if normotensive with normoalbuminuria.

Once any albuminuria develops, ACE inhibitors can decrease urinary albumin. Bilous et al. [96] presented a meta-analysis of 12 studies to answer whether type $1 \mathrm{DM}$ with microalbuminuria and normotension should receive ACE inhibitors [97]. Interestingly, 5 out of 12 studies included what would now be considered hypertensive type $1 \mathrm{DM}$ subjects. Regardless, they showed a $62 \%$ decrease in progression in nephropathy and a three-fold greater risk of regression to normal or low albuminuria with use of ACE inhibitor therapy [97]. Therefore, ACE inhibitors should be prescribed to diabetics with evidence of microvascular disease (ie. albuminuria).

Hypertension: Prior to the availability of ACE inhibitors, antihypertensive therapy decreased albuminuria by $50 \%$ and slowed the rate of decline of GFR $[98,99]$. Medications used to show this benefit were metoprolol, hydralazine, furosemide, and spironolactone. Mean BP achieved was $120-140 / 80-90 \mathrm{mmHg}$ in these studies $[98,99]$.

In 1993, Lewis et al. published the RCT that compared captopril to placebo in type 1 diabetics with albuminuria and CKD [100]. The captopril arm showed favorable results with respect to albuminuria reduction, less doubling of serum creatinine, decrease in creatinine clearance decline rate and the combined end-points of dialysis, transplantation and death. However some of the benefit seen could have been due to the $2 / 4 \mathrm{mmHg}$ BP difference in the two groups [100].

Therefore, as supported by KDIGO, hypertension with albuminuria or $\mathrm{CKD}, \mathrm{ACE}$ inhibition is the first choice, with ARBs a possible alternative if intolerant to ACE inhibitors. If BP above $130 / 80 \mathrm{mmHg}$ with normoalbuminuria and normal renal function, then choices include ACE inhibitor/ARB, CCBs and thiazides (alphabetical order) [7].

\section{Type 2 primary prevention}

Two studies have studied interventions to prevent microalbuminuria in normoalbuminuric patients with diabetes. The BENEDICT trial, a multicentre double blind randomized study, followed 1204 subjects in four groups, trandolapril plus verapamil, trandolapril alone, verapamil alone and placebo [101]. After 4 years of follow-up, the placebo group had a higher rate of progression to microalbuminuria than the trandolapril plus verapamil group [101]. Similarly, the ROADMAP study, assessed the effect of olmesartan on the rate of development of microalbuminuria in normoalbuminuric type 2 diabetics [102]. Time to first onset of microalbuminuria was increased in the olmesartan 
group compared to placebo by $23 \%$, with a hazard ratio of $0.77(0.63-$ 0.94 ), which reached statistical significance. There was increased risk of mortality detected in the olmesartan group which could be attributed to by chance due to the low number of events. There was a tendency towards more events in the quartile with lowest BP and the quartile with the highest BP change, i.e. decrease in subjects who had preexisting cardiac disease. The aggressive BP target may be the reason for the increased mortality noted in the subjects with known cardiac disease.

For now, in normotensive type 2 diabetic with normoalbuminuria it is not recommended to start an ACE inhibitor or ARB.

\section{BP Target for CKD with Normal Albuminuria}

In the UKPDS trial, 1148 individuals with type $2 \mathrm{DM}$ were randomized to a target blood pressure of $150 / 85 \mathrm{mmHg}$ or below versus less tight control (less than 180/105 $\mathrm{mmHg}$ ) using atenolol or captopril [103]. Mean follow-up for the original study was 8.4 years. Risk of progressive diabetic nephropathy was included in the microvascular complications, which were reduced by $37 \%$ with "tight" blood pressure control.

HOT studied 18790 subjects, with $8 \%$ diabetics to evaluate the association of cardiovascular events and diastolic blood pressure, randomized to 90,85 , or $80 \mathrm{mmHg}$ or less [104]. Among the diabetics, there was a $51 \%$ reduction of cardiovascular events in the 80 compared to $90 \mathrm{mmHg}$ group. Albuminuria information was not available.

ABCD were 2 randomized clinical trials that assessed 950 type 2 DM normotensive and hypertensive subjects with respect to intensive and standard blood pressure control [105]. The hypertensive group were divided to target $75 \mathrm{mmHg}$ or between $80-90 \mathrm{mmHg}$ of diastolic BP. The normotensive group were divided to target a $10 \mathrm{mmHg}$ decrease in BP in the intensive group and no change in the control group. The intensive group did not show any improvement in kidney or cardiovascular outcomes. This may be due to the effect of nisoldipine, which was associated with increased cardiac events. However a significant decrease in mortality was noted in the intensive BP group (5.5 vs. $10.7 \% \mathrm{p}=0.037$ ) [105].

In the normotensive groups, the intensive control group showed decrease in albuminuria progression, retinopathy progression and stroke events.

The ACCORD study randomized 4687 type 2 diabetics with hypertension to systolic BP goal of less than $120 \mathrm{mmHg}$ versus less than $140 \mathrm{mmHg}$ [106]. No benefit in cardiovascular disease events was found with the intensive group, except for a lower risk of stroke.

The ADVANCE trial examined 11,140 type 2 diabetic patients over the age of 55 and showed that intensive blood pressure control (below 135/80 $\mathrm{mmHg}$ ) with fixed dose perindopril and thiazide had a risk reduction of $21 \%$ for all renal events, defined as new-onset albuminuria and macroalbuminuria [107]. The study achieved a 5.6 $\mathrm{mmHg}$ difference in systolic and $2.2 \mathrm{mmHg}$ difference in diastolic blood pressures over the 4.3 years. Combined macrovascular and microvascular events decreased by $9 \%$ with more intensive BP control. On secondary analyses, lower BP less than 120/70 $\mathrm{mmHg}$ had lower risk of diabetic nephropathy progression [108].

MRFIT was a large observational study that followed 347,978 men for 12 years [109]. The cohort included 5,163 diabetics. When baseline $\mathrm{BP}$ was divided into quintiles, the highest quintile was associated with highest risk of ESRD. In the subgroup of diabetics, the risk of cardiovascular disease was strongly associated with BP.
In another observational study, 11,912 men were followed for 15 years and confirmed the association between high pre-treatment hypertension $(165-180 \mathrm{mmHg}$ systolic and $>180$ systolic $\mathrm{mmHg}$ ) and increased risk of ESRD [110]. This study included 901 diabetics. Similar results were found by the Okinawan study, a large cohort of men and women who were followed for 17 years and described a significant association between baseline BP and ESRD risk [111].

For type 1 diabetes, 10 year observational cohorts of 589 subjects were studied for predictors of mortality and cardiovascular events [112]. With reference of $<110$ systolic BP, 120-129 $\mathrm{mmHg}$ and $>130$ $\mathrm{mmHg}$ had a RR of 3.0 and 7.2 for mortality and 2.5 and 6.0 for cardiovascular events, respectively. A diastolic BP $90 \mathrm{mmHg}$ or greater was most significantly associated with mortality and cardiovascular events.

Post hoc analyses of the IDNT revealed that BP less than 120/85 $\mathrm{mmHg}$ was associated with higher risk of fatal cardiovascular and congestive heart failure events but a lower risk of stroke [113]. Blood pressure approaching 120/85 $\mathrm{mmHg}$ was associated with decreased fatal cardiovascular and congestive heart failure events. The safety of targeting BP below $120 / 85 \mathrm{mmHg}$ is questionable with these results.

Similarly post hoc analyses of the ONTARGET study showed that $\mathrm{BP}<130 / 80 \mathrm{mmHg}$ among the diabetic patients in the study resulted in a J-shaped curve response to cardiovascular events and cardiovascular mortality [114]. Essentially a systolic BP less than $130 \mathrm{mmHg}$ had a risk of increased events in the subgroup compared to $130-140 \mathrm{mmHg}$. The subjects who had an event with systolic BP below $130 \mathrm{mmHg}$ were more likely to have pre-existing vascular disease [114].

In the subgroup analyses of INVEST, looking at hypertensive diabetics and intensity of BP control found a significant increase in mortality and combined outcome of death, stroke and MI if the systolic $\mathrm{BP}$ was greater than $140 \mathrm{mmHg}$ [115]. There was no difference between usual care (130-140 $\mathrm{mmHg}$ ) and intense $\mathrm{BP}$ control $(<130 \mathrm{mmHg})$.

From these studies, there is strong evidence to lower BP below 140/90 mmHg. Below 130/80 $\mathrm{mmHg}$ has brought up some concerns, especially is the subgroup of diabetics who may have glomerular nephrosclerosis and other vascular disease. These individuals could be at risk of cardiovascular mortality as per the post ad hoc analyses. Thus, KDIGO recommended BP target of less than 140/90 $\mathrm{mmHg}$ in adult with $\mathrm{DM}, \mathrm{CKD}$ and normoalbuminuria [7]. A separate recommendation has been given for $\mathrm{BP}$ goal of $<130 / 80 \mathrm{mmHg}$ in adult with DM, CKD and albuminuria [7].

\section{RAAS Blockade}

The landmark studies in type 2 DM for RAAS blockade were the RENAAL and IDNT trials that both used ARBs [116,117]. RENAAL showed losartan therapy compared to placebo led to a reduction in the doubling of serum creatinine by $25 \%$ and ESRD by $28 \%$. Similarly in IDNT among type $2 \mathrm{DM}$ with nephropathy, irbesartan was able to lower doubling of serum creatinine by $33 \%$ and ESRD by $23 \%$ in the 2.6 years of follow-up. Further analyses of IDNT showed that lowering proteinuria lowered the risk of kidney failure proportionally [118]. The repeat analyses were done to further justify irbesartan effect on lowering proteinuria, which in turn lowers the risk of ESRD, not related to the blood pressure.

An early reduction in albuminuria with angiotensin blocking agents attenuates the decline in GFR [119]. The larger the decline in albuminuria using irbesartan resulted in a slower decline in estimated 
GFR [119]. Those who exhibited more than $50 \%$ reduction in their albuminuria, had a rate of decline of $1 \mathrm{ml} / \mathrm{min} / 1.73 \mathrm{~m}^{2}$ compared to those who had a rise of more than $34 \%$, who had more than a $2 \mathrm{ml} /$ $\mathrm{min} / 1.73 \mathrm{~m}^{2}$ decline in GFR.

Other studies of significance with respect to cardiovascular mortality include the following.

Steno Diabetes Centre enrolled 160 patients with type $2 \mathrm{DM}$ and randomized them to intensive multifactorial intervention, including life style modification, smoking cessation, physical activity, treatment of dyslipidemia, glycemic control and blood pressure management or conventional care [120]. There was increase proportion of patients on ACE inhibitor or ARB at the end of the study. After 7.8 years of treatment, they found a strong association between intensive group and decreased cardiovascular mortality (HR $0.43 ; 95 \% \mathrm{CI}, 0.19$ to 0.94 ) and cardiovascular events (HR $0.41 ; 95 \% \mathrm{CI}, 0.25$ to 0.67 ) [121].

The LIFE study was designed to assess the difference between losartan and beta blockade in the development of cardiovascular outcomes in patients with LVH and hypertension [122]. In subgroup analyses of the diabetics in the population (1063), increasing albuminuria was associated with increased cardiovascular events [123]. Reduction in albuminuria occurred more with losartan than atenolol groups. Losartan was protective against cardiovascular events.

Low dose ramipril was not found to be effective in preventing renal or cardiovascular outcomes in a randomized trial of over 4000 subjects with type 2 DM [124].

In a randomized controlled study of 94 subjects with type $2 \mathrm{DM}$, normotensive with albuminuria were treated with ACE inhibitor or placebo. There was an absolute risk reduction of nephropathy of $42 \%$ from the treatment [125]. Similar results were noted with telmisartan in a RCT which enrolled 527 subjects with type $2 \mathrm{DM}$ and microalbuminuria [126]. The progression to severe albuminuria was decreased in a dose response manner, since there were three treatment arms, $80 \mathrm{mg}$ or $40 \mathrm{mg}$ of telmisartan and placebo.

There are many studies that show that ARBs and ACE inhibitors decrease albuminuria [125,127-129]. The reduction in albuminuria ranges revises $15 \%$ to $50 \%$, depending on the dose of the agent and duration of treatment. Higher doses and longer duration is associated with largest reduction.

Individual ACE inhibitor or ARB doses can be maximized to lower proteinuria, irrespective of blood pressure lowering; however, the long-term effects of a high dose monotherapy strategy is not known $[130,131]$. Increasing the dose of irbesartan from $300 \mathrm{mg}$ to $900 \mathrm{mg}$ daily, resulted an additional reduction in urine albumin excretion of $15 \%$ [130]. There was also a further decline among the high dose irbesartan group in the systolic and diastolic BP. High dose valsartan at $640 \mathrm{mg}$ daily increased the regression to normoalbuminuria by double compared to $320 \mathrm{mg}$ dose in type $2 \mathrm{DM}$ with moderate albuminuria [131]. One should only consider this approach if the serum potassium levels are monitored regularly and remain in safe levels.

\section{ACE inhibition vs. ARB}

Ace inhibitors are first choice for type $1 \mathrm{DM}$ with hypertension or albuminuria because of the DCCT trial [100] showing captopril to reduce renal outcomes and combined dialysis, transplantation and death compared to the control group. In type 2DM, IDNT [117] and RENAAL [116] have shown significant reduction in renal outcomes alone and combined renal and mortality outcomes. The two classes are able to reduce albuminuria and renal outcomes comparably. In a 5 year randomized control trial comparing telmisartan to enalapril use in type $2 \mathrm{DM}$ subjects with albuminuria, these medications were equivalent in GFR decline and ESRD events. There was a low rate of mortality and similar in both groups [132].

Systematic review and meta-analysis was completed by Strippoli et al. to compare Ace inhibitors trials and ARB trials with respect to renal outcomes and mortality [133]. The two were comparable when they were compared to placebo groups in reduction of risk of ESRD, reduce progression from moderate to severe albuminuria, and doubling of serum creatinine. However, Ace inhibitors were associated with lower overall mortality whereas ARBs were not [133].

For now we do assume they are equivalent, but one should consider ace inhibition first in type $1 \mathrm{DM}$ and $\mathrm{ARB}$ in type $2 \mathrm{DM}$.

\section{Dual angiotensin II blockade}

If RAAs blockade is protective with one agent, then more than one agent should lower proteinuria even further and improve outcomes. Several studies have tested this paradigm. As anticipated, the CALM study showed that a further decline in proteinuria with combination ACE inhibitor (lisinopril) and ARB (candesartan) by $50 \%$ [134]. Yet among those with microalbuminuria, combination therapy did not lower the albuminuria more than the lisinopril group alone [134].

Even if reduction in proteinuria occurs, it may not lead to better outcome, especially with those individuals with known higher risk of cardiovascular disease. ONTARGET randomized over 25,000 subjects with high cardiovascular risk including diabetic patients in three groups: ramipril, telmisartan or both [135]. The combined therapy was associated with higher risk of hypotension and worsening renal outcomes. Moreover, there was no macrovascular outcome benefit [135]. A recent meta-analysis supports the same result that combination therapy is associated with a higher risk of worsening renal failure, more events of hypotension and hyperkalemia [136].

Two reviews have been published on this topic. Makani et al. published a meta-analysis of all trials that had studied ACE inhibitor an ARB combination [136]. In the 33 randomized studies reviewed, no benefit was noted with all-cause mortality, or mortality in CHF [136]. However an increased risk of $41 \%$ in renal failure and $55 \%$ increased risk of hyperkalemia [136]. Maione et al. carried out a systematic review of 35 studies, and found that ACE inhibitors compared to placebo had a significant reduction in nonfatal cardiovascular events (RR $0.88,95 \%$ CI 0.82-0.94) which were not found with ARB compared to placebo or combination therapy of ARB and ACE inhibition [137]. Combination therapy did not show any benefit in mortality but increased risk of hyperkalemia and hypotension were noted.

Combination therapy may have a role in those individuals who have severe albuminuria. Further studies would be needed to answer this question in macroalbumiuric type 2 diabetes populations. Two large studies LIRICO [138] and VA NEPHRON-D [139] will address the effects of combination ACE inhibitor and ARB on renal outcomes.

As of now, dual therapy is not recommended due to lack of evidence showing benefit and there is now evidence that it may cause harm.

\section{Direct Renin Inhibitors}

Since RAAS has been implicated in potentiating tubuolointerstial fibrosis in kidney disease, inhibition of renin would decrease angiotensin II levels further [140]. Aliskiren, a direct renin inhibitor, 
has been found to be effective in lowering $\mathrm{BP}$ and lower proteinuria $[141,142]$. However the ALTITUDE study to combine ARB and Aliskiren, resulted in early termination of the study to due higher risk of cerebrovascular events [143]. The combination therapy of ARB or ACE inhibition and Aliskiren is not deemed to be safe.

\section{Aldosterone Antagonists}

Aldosterone is a profibrotic agent for myocardium and kidneys [144]. This hormone is able to activate NADPH oxidase which increases oxidative species in the mesangial cells [145]. Through the activation nuclear factor $\mathrm{kB}$, it potentiate the production of proinflammatory and profibrotic agents such CTGF and TGF beta [144]. To prevent further progression of diabetic nephropathy, aldosterone antagonists have been used to lower proteinuria [146]. In combination with ARB and ACE inhibitors, further proteinuria reduction with aldosterone antagonists has been documented [147]. Spironolactone and eplerenone may show better long term results since the cardiovascular literature has found these medications effective in lowering risk of cardiovascular mortality in high risk congestive heart failure populations [148,149]. Aldosterone antagonists are associated with more episodes of hyperkalemia and serum creatinine rise [150]. It is best to avoid use of this class if the serum potassium is above $4.5 \mathrm{mmol} / \mathrm{l}$, especially with evidence of $\mathrm{CHF}$ [151]. Large RCT studies still need to address the long term renal and cardiac outcomes.

\section{Calcium channel blockers}

Among type 2 DM patients with macroalbuminuria, nondihydropyridine calcium channel blockers, i.e. diltiazem and verapamil have shown to significantly reduce proteinuria [152]. Bakris et al. compared ACE inhibitors, non-dihyrdropyridines and beta blockers on proteinuria reduction [152]. The results were similar for the lisinopril or non dihydropyridine groups. However, atenolol did not reduce proteinuria despite equivalent blood pressure reduction. This was also confirmed in a systematic review [153].

When sustained release verapamil was added to trandolapril and compared to a beta blocker, diuretic plus trandolapril arm in the INVEST study [154], no difference in the composite outcome of mortality and cardiovascular events was noted with a two-year follow up.

ASCOT BLA was another study of over 19,000 subjects randomized to combined ACE inhibitor and calcium channel blocker (amlodipine) and the group with beta-blocker and diuretic regimen in a high risk hypertensive population [155]. Amlodipine plus perindopril showed significant risk reduction in cardiovascular endpoints and new onset diabetes. The study was terminated earlier due to the beneficial results of amlodipine plus perindopril [155].

The subgroup with diabetes in ASCOT, 5137 subjects, the benefit of the amlodipine based regimen persisted with a reduction in cardiac events and procedures by $14 \%$, which was statistically significant [156].

In another large hypertensive trial (ACCOMPLISH), about $60 \%$ of their enrollment of 11506 were diabetic [157]. The investigators randomized the subjects into two groups, benzapril plus amlodipine and benzapril plus thiazide. The mean follow up was 3 years. In this study, benzapril plus amlodipine arm showed a relative risk reduction of $19.6 \%$ in the composite outcome of cardiovascular mortality, MI, stroke, cardiac hospitalizations and coronary artery procedures [157].

For reduction in albuminuria, addition of a non dihydropyridine can be considered. However for cardiovascular risk management,
ACE inhibitor combined with amlodipine as the second line therapy over beta blockers and thiazides should be considered. KDIGO will be reviewing the medications used in treatment of hypertension in the near future.

\section{Beta blockers}

Tighter control of blood pressure was achieved with captopril and atenolol in the UKPDS trial and both drugs were equally as effective in lowering risk of macrovascular and microvascular complications in type 2 diabetes [158].

The ACCOMPLISH trial studied high risk cardiovascular hypertensive patients including diabetes mellitus cases and found benzapril and amlodipine combination lowered risk of CKD progression, as compared to benazepril and thiazides [157]. Of note, the majority of the patients had normoalbuminuria or microalbuminuria, again suggesting more nephrosclerosis rather than diabetic nephropathy.

With the results of ASCOT [155] and INVEST [154], beta blockers should not be the first choice in uncomplicated hypertension management. Definitely, if the patient has previous history of MI, angina, CHF or arrhythmias, then beta blockade is preferred.

Betablockers should not be combined with nondihydropyridine calcium channel blockers due to increased risk of bradycardia [7].

\section{Diuretics}

Since the purpose with the diuretics is to induce naturiesis, in order to help out especially in cases with fluid overload. The combination of an ACE inhibitor or ARB with thiazides, allow better control of hyperkalemia. Hydrochlorothiazide, chlorthalidone and indapamide are diuretics used to treat BP and fluid overload states [159]. Hydrochlorothiazides can induce metabolic derangements, hyperuricemia, hyperlipidemia and hyperglycemia, thus should be avoided in metabolic syndrome [160].

\section{Dyslipidemia}

Several studies have shown that statins lower proteinuria in animal models and clinical trials $[161,162]$. However, no conclusive studies have shown prevention or delay of the progression of renal disease in diabetes. The SHARP trial is the only one to show a benefit in a composite outcome with statin and ezetimibe in CKD and dialysis patients, which included individuals with diabetes mellitus [163]. Time to dialysis was no difference between the two groups among the CKD subgroups. With the intense lipid therapy studied by ACCORD lipid trial, where 5518 subjects with type $2 \mathrm{DM}$ were randomized to fenofibrate or placebo in combination with simvastatin. The study did not show any reduction in progression of diabetic nephropathy [164].

Other studies conducted in CKD populations such as the $4 \mathrm{D}$ [165] and Fellström et al. [166] have been negative with respect to prevention of mortality. Possible reasons for lack of benefit shown with these studies were small sample size, low dose of statin (4D), prevalent patient on dialysis and duration of follow up. However in the subgroup of diabetes in Aurora, cardiovascular events were decreased with statin therapy [167].

To lower cardiovascular risk, there are several large RCTs that have addressed this question in the general populations. CARDS is a UK study that randomized 2838 type 2 DM subjects for primary prevention to atorvastatin $10 \mathrm{mg}$ daily and placebo groups [168]. Study 
was terminated early due to a significant positive result of the treatment arm, rate reduction $37 \%$ [95\% CI -52 to -17], $\mathrm{p}=0.001$ [167].

An interesting subgroup analysis was published from the Treat to New Target study, which enrolled 9656 subjects with renal data [169]. The groups were divided into CKD vs. non-CKD populations, and DM represented $18 \%$ and $13 \%$ respectively. The original study randomized subjects to atorvastatin $10 \mathrm{mg}$ daily or $80 \mathrm{mg}$ daily [169]. In CKD subjects, the higher dose of atorvastatin reduced cardiovascular events by $32 \%$ and in the non CKD group by $15 \%$. Higher doses in CKD can cause rhabdomyolysis and myopathy [169].

The CTT investigators reported a meta analysis studying over 18000 patient with type $2 \mathrm{DM}$ and their risk of mortality and vascular events [170]. All-cause mortality had a proportional reduction by $9 \%$ in the treatment group and the proportional reduction of vascular events by $21 \%$, both statistically significant [170].

Given the high risk of cardiovascular disease in DM, especially with CKD and albuminuria, statins are recommended at low dose and increase as tolerated to aim for $\mathrm{LDL}<$ or equal to $2.0 \mathrm{mmol} / \mathrm{l}$ [7].

\section{Agents with Negative Results or Potential Harm}

Thiazolidione/PPAR gamma agents lower serum glucose through improving insulin sensitivity [171]. Pioglitazone in particular has been shown to lower the profibrotic transforming growth factor-beta 1 levels in the urine [171]. In short term clinical studies and in animal models, these drugs decrease proteinuria $[172,173]$.

Due to higher cardiovascular complications, these agents have fallen out of favour [174]. Pioglitazone is the one available due to no increased risk of cardiac mortality, however, it is known to cause fluid retention, and an increased risk of bladder cancer has been documented [174]. Other ligands for nuclear factor receptor are being investigated, including dual PPAR gamma and alpha along with partial PPAR gamma agents [175]. For now the use of these drugs should be used with caution until their adverse risk profiles are better understood.

\section{Endothelin antagonists}

Endothelin 1 through endothelin A receptors has an important role in vasoconstriction and regulation of the immune system [176]. In diabetic nephropathy, endothelin 1 levels are increased and contribute to proteinuria and glomerulosclerosis [177-179]. The ASCEND trial studied the effects of endothelin A receptor antagonist in the type $2 \mathrm{DM}$ population and found increased cardiac deaths, higher fluid retention and congestive failure despite a reduction in the albumin creatinine ratios [180]. One of the possibilities put forth were that the endothelin $B$ receptors were also inhibited at high levels of Avosentan [180]. It is unknown whether a more specific endothelin receptor inhibitor will have less cardiac adverse effects.

\section{Bardoxolone methyl}

Bardoxolone is an antioxidant with anti-inflammatory activity that works through the KEAP1-Nrf2 pathway [181]. Early studies seemed promising in improving GFR but the BEACON Trial was terminated early due to increase adverse events and mortality noted in the Bardoxolone arm [182]. Since the results have not been published with details, it is unclear if this class will have further to offer in the delay of progression of diabetic nephropathy. One plausible explanation for the negative outcomes is that the increase in GFR and increase in albuminuria was a sign of worsening hyperfiltration of diabetic nephropathy [183].

\section{AGE inhibitors}

Advanced Glycation End products (AGE) are by products of hyperglycemia induced metabolic state [184]. At the kidneys, ACE compounds promote mesangial expansion, induce TGF Beta overexpression in podocytes and increase GBM permeability [185]. Receptors for AGE have an important role to bind to AGE allow removal of these substances.

Areas to target in order to inhibit AGE activity are preventing the formation of AGE, inhibiting AGE cross linkage, and interaction with the AGE receptor [181].

Aminoguanidine (Pimagedine), an AGE inhibitor, was tested in a randomized control trial for type 2 diabetes mellitus but was terminated due to other significant adverse events, such as glomerulonephritis and lupus like reactions [186]. Pyridoxine, another AGE inhibitor, was studied as a randomized control trial but there was no significant improvement in renal function or albuminuria [187]. A B6-derivative, pyridoxal-5 phosphate is being studied in a randomized control trial in type 2 diabetics [181].

\section{Vitamin $\mathrm{E}$ and haptoglobins}

Haptoglobin is a hemoglobin binding protein [188]. Haptoglobin binds to hemoglobin, to make a complex that is recognized by CD163 receptor on macrophages from the liver. There are 2 alleles of haptoglobin, which results in three genotypes: Hp1 Hp1, Hp2 Hp2, Hp2 Hp1 [188]. Hp can bind to APOA1 on HDL alone or with hemoglobin. Normally Hp blocks the oxidation of LDL by hemoglobin, but in diabetics increased LDL oxidation occurs through haemoglobin [188].

Diabetic with Hp2Hp2 phenotype have a higher cardiac event rates compared to the other phenotypes [189]. Vit E has been used to decrease the LDL oxidation in this phenotype [189]. ICare Study randomized 1434 subjects to Vit E or placebo and followed them for 18 months [190]. A 50\% reduction in the primary composite outcome, MI, stroke and cardiovascular death, was reported. There is even a further benefit when statins were combined with Vit E in this group when subanalyses of the ICARE study included 801 patients and found a $68 \%$ reduction in the primary outcome [190].

This is example of why certain therapies may fail if the underlying genetic information is not known.

\section{Some Potential Therapies for Diabetic Nephropathy}

Dipeptidyl peptidase 4 inhibitors /GLP-1 mimetic: incretins are hormones released in the gastrointestinal tract in response to a glucose load [191]. They stimulate pancreatic insulin secretion and inhibit glucagon secretion. GLP1 (glucagon-like peptide- 1) and GIP (gastric inhibitory peptide) are incretins that are broken down by DDP IV [191].

There are two classes in this group: DDP IV inhibitors which prevent the breakdown of incretins and GLP-1 mimetic which works as an incretin receptor agonist to prevent degradation [191].

DDP IV inhibitors have shown to reduce albuminuria in humans and in animal models [192,193]. GLP-1 mimetics such as Exenatide and Liraglutide decrease glomerular injury in diabetic animal models $[194,195]$. Long term effects in humans have yet to be determined.

\section{Sodium-coupled glucose cotransporter 2 inhibitors}

Another class of anti-glycemic agents is the sodium-coupled 
glucose cotransporter 2 inhibitors. Glucose reabsorption occurs in the proximal tubules using a secondary active cotransporter, coupled with sodium [196]. The majority of the glucose $90 \%$ is reabsorbed through the SGLT2, mostly found in renal and intestine. A phlorizin derivative is able to inhibit the activity of this cotransporter and result in glucosuria. Initial studies have shown these agents are able to lower serum glucose, lower weight, and lower blood pressure [197]. However this may come with the risk of increased urinary tract infections, genitourinary infections and volume depletion from osmotic diuresis. This class of medications lower GFR acutely, then increases after weeks, but remains below baseline. Albuminuria also decreases, but it is unclear whether this decline is due to a GFR decline or a response to better glycemic control [198].

\section{Connective Tissue Growth Factor (CTGF)}

CTGF increases the activity of profibrotic cytokines such as TGF beta and promotes fibrosis [199]. The high expression in podocytes is reported with increased activity in hyperglycemia [200]. FG-3019, a human monoclonal antibody to CTGF has shown to reduce proteinuria in type 2 DM subjects [201]. Larger randomized trials are awaited.

\section{Vitamin D}

In the proximal tubules, the 1 - hydroxylase converts $25 \mathrm{OH}$ vitamin D to $1,25 \mathrm{OH}$ vitamin $\mathrm{D}$ (choleciferol). In animal models, vitamin $\mathrm{D}$ receptor activation resulted in lower albuminuria and less severe glomerulosclerosis [202]. Vitamin D is also been shown to have an inhibitory effect on the RAAS [203]. 1, 25 OH Vit D directly suppresses plasma renin expression and activity [203]. In humans, $25 \mathrm{OH}$ Vit D deficiency and insufficiency was associated with higher Ang II and renin levels compared to sufficient Vit D 25OH individuals [204]. Vit $\mathrm{D}$ also has anti-inflammatory effects by decreasing proinflammatory cytokines such as TNF and IL6, and promotes anti-inflammatory cytokines like IL10 [204]. Endothelial dysfunction has been reported in type 2 DM with Vit D deficiency [205,206]. Also, severe 25 OH Vit D deficiency has been associated with increased cardiovascular mortality in an observational study [207].

A parallel RCT of 61 subjects looked at type $2 \mathrm{DM}$ with low Vit D levels and replaced one group with 10,000 units per week, another with 20000 units per week and third with placebo [208]. The study only was followed for 16 weeks, but a significant decrease in BP and decrease in BNP levels were noted.

Thus the VITAL study was carried out, randomized 281 subjects with type $2 \mathrm{DM}$ to placebo, $1 \mathrm{ug} /$ day paricalcitol, $2 \mathrm{ug} /$ day paricalcitol and followed for 24 weeks of therapy and a two month follow up period after study intervention was discontinued [209]. Though the $1 \mu \mathrm{g} /$ day dose was unable to show a significant reduction in albuminuria, but the $2 \mu \mathrm{g} /$ day regimen decreased albuminuria by a $20 \%$ difference compared to placebo. The benefits seen in this study have been attributed to Vitamin D insufficiency and repletion improved albuminuria [210].

An RCT with long-term follow up is warranted to assess if additional Vitamin D, once already replete, would further be beneficial.

\section{Summary}

The mainstay of therapy should first rely on the appropriate classification of kidney disease in those with type $2 \mathrm{DM}$ and then implement therapies accordingly. Novel biomarkers in addition to albuminuria may provide promise in better identifying those with diabetic nephropathy.
Taevert's histopathology scoring system is advantageous especially if you apply the scores for the tubulointerstitial disease. Albuminuria appearance, response to therapy, and baseline GFR determine the rate of decline in renal function. Angiotensin blockade is warranted, but dual angiotensin blockade for overt proteinuria should notbe used due to safety concerns. Introducing an aldosterone antagonist is a potential approach to improve renal outcomes, but monitoring for hyperkalemia is essential. Recent large clinical trials such as ROADMAP, ADVANCE and ACCORD have challenged the targets for BP control in type 2 DM. Aiming below $120 / 85 \mathrm{mmHg}$ is not universally appropriate. A glycated hemoglobin of $7 \%$ is supported by the ACCORD trial, with serious hypoglycemic events noted with more intensive therapy. The performance of newer therapies such as endothelin 1 antagonists and Bardoxolone has been disappointing, but other possible therapeutic agents remain to be evaluated.

\section{References}

1. (2011) National Center for Chronic Disease Prevention and Health Promotion, National Diabetes Facts sheet 2011.

2. Pelletier C, Dai S, Roberts KC, Bienek A, Onysko J, et al. (2012) Report summary. Diabetes in Canada: facts and figures from a public health perspective. Chronic Dis Inj Can 33: 53-54.

3. Newhook LA, Penney S, Fiander J, Dowden J (2012) Recent incidence of type 1 diabetes mellitus in children 0-14 years in Newfoundland and Labrador, Canada climbs to over 45/100,000: a retrospective time trend study. BMC Res Notes 5: 628 .

4. U S. Renal Data System (2009) USRDS 2012 Annual Data Report: Atlas of End-Stage Renal Disease in the United States, National Institutes of Health, National Institute of Diabetes and Digestive and Kidney Diseases, Bethesda.

5. Kanwar YS, Sun L, Xie P, Liu FY, Chen S (2011) A glimpse of various pathogenetic mechanisms of diabetic nephropathy. Annu Rev Pathol 6: 395423.

6. National Kidney Foundation (2002) K/DOQI clinical practice guidelines for chronic kidney disease: evaluation, classification, and stratification. Am J Kidney Dis 39: S1-266.

7. KDIGO (2013) Chapter 1: Definition and classification of CKD. KI supplement 3: $19-62$.

8. Reutens AT (2013) Epidemiology of diabetic kidney disease. Med Clin North Am 97: 1-18.

9. Viberti GC, Hill RD, Jarrett RJ, Argyropoulos A, Mahmud U, et al. (1982) Microalbuminuria as a predictor of clinical nephropathy in insulin-dependent diabetes mellitus. Lancet 1: 1430-1432.

10. Mogensen CE, Christensen CK (1984) Predicting diabetic nephropathy in insulin-dependent patients. N Engl J Med 311: 89-93.

11. Hovind P, Tarnow L, Rossing K, Rossing P, Eising S, et al. (2003) Decreasing incidence of severe diabetic microangiopathy in type 1 diabetes. Diabetes Care 26: $1258-1264$

12. Nordwall M, Bojestig M, Arnqvist HJ, Ludvigsson J, Linköping Diabetes Complications Study (2004). Declining incidence of severe retinopathy and persisting decrease of nephropathy in an unselected population of Type 1 diabetes-the Linköping Diabetes Complications Study. Diabetologia 47: 1266 1272.

13. Parving HH, Andersen AR, Smidt UM, Christiansen JS, Oxenbøll B, et al. (1983) Diabetic nephropathy and arterial hypertension. The effect of antihypertensive treatment. Diabetes 32: 83-87.

14. de Boer IH, Rue TC, Cleary PA, Lachin JM, Molitch ME, et al. (2011) Long-term renal outcomes of patients with type 1 diabetes mellitus and microalbuminuria: an analysis of the Diabetes Control and Complications Trial/Epidemiology of Diabetes Interventions and Complications cohort. Arch Intern Med 171: 412420.

15. Mathiesen ER, Oxenbøll B, Johansen K, Svendsen PA, Deckert T (1984) Incipient nephropathy in type 1 (insulin-dependent) diabetes. Diabetologia 26 406-410. 
Citation: Iqbal S, Alam A (2013) Renal Disease in Diabetes Mellitus: Recent Studies and Potential Therapies. J Diabetes Metab S9: 006. doi:10.4172/2155-6156.S9-006

Page 12 of 16

16. Parving $\mathrm{HH}$, Hommel E, Mathiesen E, Skøtt P, Edsberg B, et al. (1988) Prevalence of microalbuminuria, arterial hypertension, retinopathy and neuropathy in patients with insulin dependent diabetes. Br Med J (Clin Res Ed) 296: 156-160.

17. Andersen AR, Christiansen JS, Andersen JK, Kreiner S, Deckert T (1983) Diabetic nephropathy in Type 1 (insulin-dependent) diabetes: an epidemiological study. Diabetologia 25: 496-501.

18. Borch-Johnsen K, Andersen PK, Deckert T (1985) The effect of proteinuria on relative mortality in type 1 (insulin-dependent) diabetes mellitus. Diabetologia 28: $590-596$

19. Steinke JM, Sinaiko AR, Kramer MS, Suissa S, Chavers BM, et al. (2005)The early natural history of nephropathy in Type 1 Diabetes: III. Predictors of 5-year urinary albumin excretion rate patterns in initially normoalbuminuric patients. Diabetes 54: 2164-2171.

20. Zerbini G, Bonfanti R, Meschi F, Bognetti E, Paesano PL, et al. (2006) Persisten renal hypertrophy and faster decline of glomerular filtration rate precede the development of microalbuminuria in type 1 diabetes. Diabetes 55: 2620-2625.

21. Perkins BA, Ficociello LH, Silva KH, Finkelstein DM, Warram JH, et al. (2003) Regression of microalbuminuria in type 1 diabetes. N Engl J Med 348: 22852293

22. Valmadrid CT, Klein R, Moss SE, Klein BE (2000) The risk of cardiovascular disease mortality associated with microalbuminuria and gross proteinuria in persons with older-onset diabetes mellitus. Arch Intern Med 160: 1093-1100.

23. Gerstein HC, Mann JF, Yi Q, Zinman B, Dinneen SF, et al. (2001) Albuminuria and risk of cardiovascular events, death, and heart failure in diabetic and nondiabetic individuals. JAMA 286: 421-426

24. Kramer HJ, Nguyen QD, Curhan G, Hsu CY (2003) Renal insufficiency in the absence of albuminuria and retinopathy among adults with type 2 diabetes mellitus. JAMA 289: 3273-3277.

25. Tapp RJ, Shaw JE, Zimmet PZ, Balkau B, Chadban SJ, et al. (2004) Albuminuria is evident in the early stages of diabetes onset: results from the Australian Diabetes, Obesity, and Lifestyle Study (AusDiab). Am J Kidney Dis 44: 792-798

26. Meisinger C, Heier M, Landgraf R, Happich M, Wichmann HE, et al. (2008) Albuminuria, cardiovascular risk factors and disease management in subjects with type 2 diabetes: a cross sectional study. BMC Health Serv Res 8: 226.

27. Jia W, Gao X, Pang C, Hou X, Bao Y, et al. (2009) Prevalence and risk factors of albuminuria and chronic kidney disease in Chinese population with type 2 diabetes and impaired glucose regulation: Shanghai diabetic complications study (SHDCS). Nephrol Dial Transplant 24: 3724-3731.

28. Dwyer JP, Parving HH, Hunsicker LG, Ravid M, Remuzzi G, et al. (2012) Renal Dysfunction in the Presence of Normoalbuminuria in Type 2 Diabetes: Results from the DEMAND Study. Cardiorenal Med 2: 1-10.

29. Raymond NT, Paul O'Hare J, Bellary S, Kumar S, Jones A, et al. (2011) Comparative risk of microalbuminuria and proteinuria in UK residents of south Asian and white European ethnic background with type 2 diabetes: a report from UKADS. Curr Med Res Opin 27: 47-55.

30. Groop PH, Thomas MC, Moran JL, Waden J, Thorn LM, et al. (2009) The presence and severity of chronic kidney disease predicts all-cause mortality in type 1 diabetes. Diabetes 58: 1651-1658.

31. Stadler M, Auinger M, Anderwald C, Kästenbauer T, Kramar R, et al. (2006) Long-term mortality and incidence of renal dialysis and transplantation in type 1 diabetes mellitus. J Clin Endocrinol Metab 91: 3814-3820.

32. Astrup AS, Tarnow L, Rossing P, Pietraszek L, Riis Hansen P, et al. (2005) Improved prognosis in type 1 diabetic patients with nephropathy: a prospective follow-up study. Kidney Int 68: 1250-1257.

33. Packham DK, Alves TP, Dwyer JP, Atkins R, de Zeeuw D, et al. (2012) Relative incidence of ESRD versus cardiovascular mortality in proteinuric type 2 diabetes and nephropathy: results from the DIAMETRIC (Diabetes Mellitus Treatment for Renal Insufficiency Consortium) database. Am J Kidney Dis 59: $75-83$.

34. Bruno G, Merletti F, Bargero G, Novelli G, Melis D, et al. (2007) Estimated glomerular filtration rate, albuminuria and mortality in type 2 diabetes: the Casale Monferrato study. Diabetologia 50: 941-948.

35. Harjutsalo V, Katoh S, Sarti C, Tajima N, Tuomilehto J (2004) Population-based assessment of familial clustering of diabetic nephropathy in type 1 diabetes. Diabetes 53: 2449-2454

36. [No authors listed] (1997) Clustering of long-term complications in families with diabetes in the diabetes control and complications trial. The Diabetes Control and Complications Trial Research Group. Diabetes 46: 1829-1839.

37. Thomas MC, Groop PH, Tryggvason K (2012) Towards understanding the inherited susceptibility for nephropathy in diabetes. Curr Opin Nephrol Hypertens 21: 195-202.

38. Shimazaki A, Kawamura Y, Kanazawa A, Sekine A, Saito S, et al. (2005) Genetic variations in the gene encoding ELMO1 are associated with susceptibility to diabetic nephropathy. Diabetes 54: 1171-1178.

39. Gu HF, Brismar K (2012) Genetic association studies in diabetic nephropathy. Curr Diabetes Rev 8: 336-344.

40. Fioretto P, Mauer M (2007) Histopathology of diabetic nephropathy. Semin Nephrol 27: 195-207.

41. Tervaert TW, Mooyaart AL, Amann K, Cohen AH, Cook HT, et al. (2010) Pathologic classification of diabetic nephropathy. J Am Soc Nephrol 21: 556563

42. Fioretto P, Mauer M (2010) Diabetic nephropathy: diabetic nephropathychallenges in pathologic classification. Nat Rev Nephrol 6: 508-510.

43. Najafian B, Mauer M (2012) Morphologic features of declining renal function in type 1 diabetes. Semin Nephrol 32: 415-422.

44. Olsen S (1999) Identification of non-diabetic glomerular disease in renal biopsies from diabetics--a dilemma. Nephrol Dial Transplant 14: 1846-1849.

45. Olsen S, Mogensen CE (1996) How often is NIDDM complicated with nondiabetic renal disease? An analysis of renal biopsies and the literature Diabetologia 39: 1638-1645.

46. Pham TT, Sim JJ, Kujubu DA, Liu IL, Kumar VA (2007) Prevalence of nondiabetic renal disease in diabetic patients. Am J Nephrol 27: 322-328.

47. Fioretto P, Mauer M, Brocco E, Velussi M, Frigato F, et al. (1996) Patterns of renal injury in NIDDM patients with microalbuminuria. Diabetologia 39: 15691576.

48. Wirta O, Helin H, Mustonen J, Kuittinen E, Savela T, et al. (2000) Renal findings and glomerular pathology in diabetic subjects. Nephron 84: 236-242.

49. Chang TI, Park JT, Kim JK, Kim SJ, Oh HJ, et al. (2011) Renal outcomes in patients with type 2 diabetes with or without coexisting non-diabetic renal disease. Diabetes Res Clin Pract 92: 198-204.

50. Mou S, Wang Q, Liu J, Che X, Zhang M, et al. (2010) Prevalence of nondiabetic renal disease in patients with type 2 diabetes. Diabetes Res Clin Pract 87: 354-359.

51. Huang F, Yang Q, Chen L, Tang S, Liu W, et al. (2007) Renal pathologica change in patients with type 2 diabetes is not always diabetic nephropathy: a report of 52 cases. Clin Nephrol 67: 293-297.

52. Lin YL, Peng SJ, Ferng SH, Tzen CY, Yang CS (2009) Clinical indicators which necessitate renal biopsy in type 2 diabetes mellitus patients with renal disease. Int J Clin Pract 63: 1167-1176.

53. Tone A, Shikata K, Matsuda M, Usui H, Okada S, et al. (2005) Clinical features of non-diabetic renal diseases in patients with type 2 diabetes. Diabetes Res Clin Pract 69: 237-242.

54. Nosadini R, Velussi M, Brocco E, Bruseghin M, Abaterusso C, et al. (2000) Course of renal function in type 2 diabetic patients with abnormalities of albumin excretion rate. Diabetes 49: 476-484.

55. Kramer HJ, Nguyen QD, Curhan G, Hsu CY (2003) Renal insufficiency in the absence of albuminuria and retinopathy among adults with type 2 diabetes mellitus. JAMA 289: 3273-3277

56. Perkins BA, Krolewski AS (2005) Early nephropathy in type 1 diabetes: a new perspective on who will and who will not progress. Curr Diab Rep 5: 455-463.

57. Okada T, Nagao T, Matsumoto H, Nagaoka Y, Wada T, et al. (2012) Histological predictors for renal prognosis in diabetic nephropathy in diabetes mellitus type 2 patients with overt proteinuria. Nephrology (Carlton) 17: 68-75.

58. Rosolowsky ET, Skupien J, Smiles AM, Niewczas M, Roshan B, et al. (2011) Risk for ESRD in type 1 diabetes remains high despite renoprotection. J Am Soc Nephrol 22: 545-553. 
Citation: Iqbal S, Alam A (2013) Renal Disease in Diabetes Mellitus: Recent Studies and Potential Therapies. J Diabetes Metab S9: 006. doi:10.4172/2155-6156.S9-006

59. Forsblom C, Harjutsalo V, Thorn LM, Wadén J, Tolonen N, et al. (2011) Competing-risk analysis of ESRD and death among patients with type 1 diabetes and macroalbuminuria. J Am Soc Nephrol 22: 537-544.

60. Costacou T, Ellis D, Fried L, Orchard TJ (2007) Sequence of progression of albuminuria and decreased GFR in persons with type 1 diabetes: a cohort study. Am J Kidney Dis 50: 721-732.

61. Adler Al, Stevens RJ, Manley SE, Bilous RW, Cull CA, et al. (2003) Development and progression of nephropathy in type 2 diabetes: the United Kingdom Prospective Diabetes Study (UKPDS 64). Kidney Int 63: 225-232.

62. [No authors listed] (1998) Tight blood pressure control and risk of macrovascular and microvascular complications in type 2 diabetes: UKPDS 38. UK Prospective Diabetes Study Group. BMJ 317: 703-713.

63. Kramer HJ, Nguyen QD, Curhan G, Hsu CY (2003) Renal insufficiency in the absence of albuminuria and retinopathy among adults with type 2 diabetes mellitus. JAMA 289: 3273-3277.

64. Garg AX, Kiberd BA, Clark WF, Haynes RB, Clase CM (2002) Albuminuria and renal insufficiency prevalence guides population screening: results from the NHANES III. Kidney Int 61: 2165-2175.

65. Perkins BA, Ficociello LH, Roshan B, Warram JH, Krolewski AS (2010) In patients with type 1 diabetes and new-onset microalbuminuria the development of advanced chronic kidney disease may not require progression to proteinuria. Kidney Int 77: 57-64.

66. Kramer HJ, Nguyen QD, Curhan G, Hsu CY (2003) Renal insufficiency in the absence of albuminuria and retinopathy among adults with type 2 diabetes mellitus. JAMA 289: 3273-3277.

67. Thomas MC, Macisaac RJ, Jerums G, Weekes A, Moran J, et al. (2009) Nonalbuminuric renal impairment in type 2 diabetic patients and in the general population (national evaluation of the frequency of renal impairment coexisting with NIDDM [NEFRON] 11). Diabetes Care 32: 1497-1502.

68. Retnakaran R, Cull CA, Thorne KI, Adler Al, Holman RR; UKPDS Study Group (2006) Risk factors for renal dysfunction in type 2 diabetes: U.K. Prospective Diabetes Study 74. Diabetes 55: 1832-1839.

69. Tramonti G, Kanwar YS (2013) Review and discussion of tubular biomarkers in the diagnosis and management of diabetic nephropathy. Endocrine 43: 494503.

70. Zürbig $P$, Jerums G, Hovind $P$, Macisaac RJ, Mischak H, et al. (2012) Urinary proteomics for early diagnosis in diabetic nephropathy. Diabetes 61: 3304 3313.

71. http//eu-priority.org (website of study).

72. Skupien J, Warram JH, Smiles AM, Niewczas MA, Gohda T, et al. (2012) The early decline in renal function in patients with type 1 diabetes and proteinuria predicts the risk of end-stage renal disease. Kidney Int 82: 589-597.

73. Amin R, Turner C, van Aken S, Bahu TK, Watts A, et al. (2005) The relationship between microalbuminuria and glomerular filtration rate in young type 1 diabetic subjects: The Oxford Regional Prospective Study. Kidney Int 68: 1740-1749.

74. Christensen PK, Larsen S, Horn T, Olsen S, Parving HH (2001) Renal function and structure in albuminuric type 2 diabetic patients without retinopathy. Nephrol Dial Transplant 16: 2337-2347.

75. Soni SS, Gowrishankar S, Kishan AG, Raman A (2006) Non diabetic renal disease in type 2 diabetes mellitus. Nephrology (Carlton) 11: 533-537.

76. Macisaac RJ, Tsalamandris C, Panagiotopoulos S, Smith TJ, McNeil KJ, et al (2004) Nonalbuminuric renal insufficiency in type 2 diabetes. Diabetes Care 27: $195-200$

77. Nosadini R, Velussi M, Brocco E, Bruseghin M, Abaterusso C, et al. (2000) Course of renal function in type 2 diabetic patients with abnormalities of albumin excretion rate. Diabetes 49: 476-484.

78. Pavkov ME, Knowler WC, Lemley KV, Mason CC, Myers BD, et al. (2012) Early renal function decline in type 2 diabetes. Clin J Am Soc Nephrol 7: 78-84.

79. Stadler K (2012) Oxidative stress in diabetes. Adv Exp Med Biol 771: 272-287.

80. Wada J, Makino H (2013) Inflammation and the pathogenesis of diabetic nephropathy. Clin Sci (Lond) 124: 139-152.

81. Busch M, Franke S, Rüster C, Wolf G (2010) Advanced glycation end-products and the kidney. Eur J Clin Invest 40: 742-755.
82. Ruggenenti $P$, Cravedi $P$, Remuzzi G (2010) The RAAS in the pathogenesis and treatment of diabetic nephropathy. Nat Rev Nephrol 6: 319-330.

83. Helal I, Fick-Brosnahan GM, Reed-Gitomer B, Schrier RW (2012) Glomerular hyperfiltration: definitions, mechanisms and clinical implications. Nat Rev Nephrol 8: 293-300.

84. [No authors listed] (1993) The effect of intensive treatment of diabetes on the development and progression of long-term complications in insulin-dependent diabetes mellitus. The Diabetes Control and Complications Trial Research Group. N Engl J Med 329: 977-986.

85. DCCT/EDIC Research Group, de Boer IH, Sun W, Cleary PA, Lachin JM, et al. (2011) Intensive diabetes therapy and glomerular filtration rate in type 1 diabetes. N Engl J Med 365: 2366-2376.

86. Tonna S, El-Osta A, Cooper ME, Tikellis C (2010) Metabolic memory and diabetic nephropathy: potential role for epigenetic mechanisms. Nat Rev Nephrol 6: 332-341.

87. Fioretto P, Mauer M (2012) Reversal of diabetic nephropathy: lessons from pancreas transplantation. J Nephrol 25: 13-18.

88. Smail N, Paraskevas S, Tan X, Metrakos P, Cantarovich M (2012) Renal function in recipients of pancreas transplant alone. Curr Opin Organ Transplant 17: 73-79.

89. Scalea JR, Butler CC, Munivenkatappa RB, Nogueira JM, Campos L, et al. (2008) Pancreas transplant alone as an independent risk factor for the development of renal failure: a retrospective study. Transplantation 86: 17891794.

90. (1998) Intensive blood-glucose control with sulphonylureas or insulin compared with conventional treatment and risk of complications in patients with type 2 diabetes (UKPDS 33). UK Prospective Diabetes Study (UKPDS) Group. Lancet 352: 837-853.

91. Ismail-Beigi F, Craven T, Banerji MA, Basile J, Calles J, et al. (2010) Effect of intensive treatment of hyperglycaemia on microvascular outcomes in type 2 diabetes: an analysis of the ACCORD randomised trial. Lancet 376: 419-430.

92. ADVANCE Collaborative Group, Patel A, MacMahon S, Chalmers J, Neal B, et al. (2008) Intensive blood glucose control and vascular outcomes in patients with type 2 diabetes. N Engl J Med 358: 2560-2572.

93. Duckworth W, Abraira C, Moritz T, Reda D, Emanuele N, et al. (2009) Glucose control and vascular complications in veterans with type 2 diabetes. $\mathrm{N}$ Engl $J$ Med 360: 129-139.

94. (2013) Canadian Diabetes Association, Clinical practice guidelines.

95. Mauer M, Zinman B, Gardiner R, Suissa S, Sinaiko A, et al. (2009) Renal and retinal effects of enalapril and losartan in type 1 diabetes. $N$ Engl J Med 361: $40-51$

96. Bilous R, Chaturvedi N, Sjølie AK, Fuller J, Klein R, et al. (2009) Effect of candesartan on microalbuminuria and albumin excretion rate in diabetes: three randomized trials. Ann Intern Med 151: 11-20, W3-4.

97. ACE Inhibitors in Diabetic Nephropathy Trialist Group (2001) Should all patients with type 1 diabetes mellitus and microalbuminuria receive angiotensinconverting enzyme inhibitors? A meta-analysis of individual patient data. Ann Intern Med 134: 370-379

98. Parving HH, Andersen AR, Smidt UM, Christiansen JS, Oxenbøll B, et al. (1983) Diabetic nephropathy and arterial hypertension. The effect of antihypertensive treatment. Diabetes 32: 83-87.

99. Mogensen CE (1976) Progression of nephropathy in long-term diabetics with proteinuria and effect of initial anti-hypertensive treatment. Scand J Clin Lab Invest 36: 383-388.

100. Lewis EJ, Hunsicker LG, Bain RP, Rohde RD (1993) The effect of angiotensinconverting-enzyme inhibition on diabetic nephropathy. The Collaborative Study Group. N Engl J Med 329: 1456-1462.

101. Ruggenenti P, Fassi A, llieva AP, Bruno S, lliev IP, et al. (2004) Preventing microalbuminuria in type 2 diabetes. N Engl J Med 351: 1941-1951.

102. Haller $\mathrm{H}$, Ito S, Izzo JL Jr, Januszewicz A, Katayama S, et al. (2011) Olmesartan for the delay or prevention of microalbuminuria in type 2 diabetes. N Engl J Med 364: 907-917.

103. [No authors listed] (1998) Efficacy of atenolol and captopril in reducing risk of macrovascular and microvascular complications in type 2 diabetes: UKPDS 39. UK Prospective Diabetes Study Group. BMJ 317: 713-720. 
Citation: Iqbal S, Alam A (2013) Renal Disease in Diabetes Mellitus: Recent Studies and Potential Therapies. J Diabetes Metab S9: 006. doi:10.4172/2155-6156.S9-006

Page 14 of 16

104. Hansson L, Zanchetti A, Carruthers SG, Dahlöf B, Elmfeldt D, et al. (1998) Effects of intensive blood-pressure lowering and low-dose aspirin in patients with hypertension: principal results of the Hypertension Optimal Treatment (HOT) randomised trial. HOT Study Group. Lancet 351: 1755-1762.

105. Schrier RW, Estacio RO, Mehler PS, Hiatt WR (2007) Appropriate blood pressure control in hypertensive and normotensive type 2 diabetes mellitus: a summary of the ABCD trial. Nat Clin Pract Nephrol 3: 428-438.

106.ACCORD Study Group, Cushman WC, Evans GW, Byington RP, Goff DC $\mathrm{Jr}$, et al. (2010) Effects of intensive blood-pressure control in type 2 diabetes mellitus. N Engl J Med 362: 1575-1585.

107. ADVANCE Collaborative Group, MacMahon S, Chalmers J, Neal B, Woodward M, et al. (2007) Effects of a fixed combination of perindopril and indapamide on macrovascular and microvascular outcomes in patients with type 2 diabetes mellitus (the ADVANCE trial): a randomised controlled trial. Lancet 370: 829-840.

108. de Galan BE, Perkovic V, Ninomiya T, Pillai A, Patel A, et al. (2009) Lowering blood pressure reduces renal events in type 2 diabetes. J Am Soc Nephrol 20: 883-892.

109. Stamler J, Vaccaro O, Neaton JD, Wentworth D (1993) Diabetes, other risk factors, and 12-yr cardiovascular mortality for men screened in the Multiple Risk Factor Intervention Trial. Diabetes Care 16: 434-444.

110. Perry HM Jr, Miller JP, Fornoff JR, Baty JD, Sambhi MP, et al. (1995) Early predictors of 15-year end-stage renal disease in hypertensive patients. Hypertension 25: 587-594

111. Tozawa M, Iseki K, Iseki C, Kinjo K, Ikemiya Y, et al. (2003) Blood pressure predicts risk of developing end-stage renal disease in men and women. Hypertension 41: 1341-1345.

112. Orchard TJ, Forrest KY, Kuller LH, Becker DJ; Pittsburgh Epidemiology of Diabetes Complications Study (2001) Lipid and blood pressure treatment goals for type 1 diabetes: 10 -year incidence data from the Pittsburgh Epidemiology of Diabetes Complications Study. Diabetes Care 24: 1053-1059.

113. Berl T, Hunsicker LG, Lewis JB, Pfeffer MA, Porush JG, et al. (2005) Impact of achieved blood pressure on cardiovascular outcomes in the Irbesartan Diabetic Nephropathy Trial. J Am Soc Nephrol 16: 2170-2179.

114. Redon J, Mancia G, Sleight P, Schumacher H, Gao P, et al. (2012) Safety and efficacy of low blood pressures among patients with diabetes: subgroup analyses from the ONTARGET (ONgoing Telmisartan Alone and in combination with Ramipril Global Endpoint Trial). J Am Coll Cardiol 59: 74-83.

115. Cooper-DeHoff RM, Gong Y, Handberg EM, Bavry AA, Denardo SJ, et al. (2010) Tight blood pressure control and cardiovascular outcomes among hypertensive patients with diabetes and coronary artery disease. JAMA 304: 61-68.

116. Brenner BM, Cooper ME, de Zeeuw D, Keane WF, Mitch WE, et al. (2001) Effects of losartan on renal and cardiovascular outcomes in patients with type 2 diabetes and nephropathy. N Engl J Med 345: 861-869.

117. Parving HH, Lehnert H, Bröchner-Mortensen J, Gomis R, Andersen S, et al. (2001) The effect of irbesartan on the development of diabetic nephropathy in patients with type 2 diabetes. N Engl J Med 345: 870-878.

118. Atkins RC, Briganti EM, Lewis JB, Hunsicker LG, Braden G, et al. (2005) Proteinuria reduction and progression to renal failure in patients with type 2 diabetes mellitus and overt nephropathy. Am J Kidney Dis 45: 281-287.

119. Hellemons ME, Persson F, Bakker SJ, Rossing P, Parving HH, et al. (2011) initial angiotensin receptor blockade-induced decrease in albuminuria is associated with long-term renal outcome in type 2 diabetic patients with microalbuminuria: a post hoc analysis of the IRMA-2 trial. Diabetes Care 34: 2078-2083

120. Gaede P, Tarnow L, Vedel P, Parving HH, Pedersen O (2004) Remission to normoalbuminuria during multifactorial treatment preserves kidney function in patients with type 2 diabetes and microalbuminuria. Nephrol Dial Transplant 19: 2784-2788.

121. Gaede P, Lund-Andersen H, Parving HH, Pedersen O (2008) Effect of a multifactorial intervention on mortality in type 2 diabetes. $\mathrm{N}$ Engl J Med 358: 580-591.

122. Ibsen $\mathrm{H}$, Olsen MH, Wachtell K, Borch-Johnsen K, Lindholm LH, et al. (2005) Reduction in albuminuria translates to reduction in cardiovascular events in hypertensive patients: losartan intervention for endpoint reduction in hypertension study. Hypertension 45: 198-202.
123. Ibsen $\mathrm{H}$, Olsen $\mathrm{MH}$, Wachtell $\mathrm{K}$, Borch-Johnsen $\mathrm{K}$, Lindholm LH, et al. (2006) Does albuminuria predict cardiovascular outcomes on treatment with losartan versus atenolol in patients with diabetes, hypertension, and left ventricular hypertrophy? The LIFE study. Diabetes Care 29: 595-600.

124. Marre M, Lievre M, Chatellier G, Mann JF, Passa P, Ménard J; DIABHYCAR Study Investigators (2004). Effects of low dose ramipril on cardiovascular and renal outcomes in patients with type 2 diabetes and raised excretion of urinary albumin: randomised, double blind, placebo controlled trial (the DIABHYCAR study). BMJ328(7438):495. Epub 2004 Feb 11. Erratum in: BMJ328(7441):686

125. Ravid M, Savin H, Jutrin I, Bental T, Katz B, et al. (1993) Long-term stabilizing effect of angiotensin-converting enzyme inhibition on plasma creatinine and on proteinuria in normotensive type II diabetic patients. Ann Intern Med 118: 577-581.

126. Makino H, Haneda M, Babazono T, Moriya T, Ito S, et al. (2007) Prevention of transition from incipient to overt nephropathy with telmisartan in patients with type 2 diabetes. Diabetes Care 30: 1577-1578.

127. Agha A, Amer W, Anwar E, Bashir K (2009) Reduction of microalbuminuria by using losartan in normotensive patients with type 2 diabetes mellitus: A randomized controlled trial. Saudi J Kidney Dis Transpl 20: 429-435.

128. ACE Inhibitors in Diabetic Nephropathy Trialist Group (2001) Should all patients with type 1 diabetes mellitus and microalbuminuria receive angiotensinconverting enzyme inhibitors? A meta-analysis of individual patient data. Ann Intern Med 134: 370-379.

129. Trevisan R, Tiengo A (1995) Effect of low-dose ramipril on microalbuminuria in normotensive or mild hypertensive non-insulin-dependent diabetic patients. North-East Italy Microalbuminuria Study Group. Am J Hypertens 8: 876-883.

130.Rossing K, Schjoedt KJ, Jensen BR, Boomsma F, Parving HH (2005) Enhanced renoprotective effects of ultrahigh doses of irbesartan in patients with type 2 diabetes and microalbuminuria. Kidney Int 68: 1190-1198.

131. Hollenberg NK, Parving HH, Viberti G, Remuzzi G, Ritter S, et al. (2007) Albuminuria response to very high-dose valsartan in type 2 diabetes mellitus. J Hypertens 25: 1921-1926.

132. Barnett AH, Bain SC, Bouter P, Karlberg B, Madsbad S, et al. (2004) Angiotensin-receptor blockade versus converting-enzyme inhibition in type 2 diabetes and nephropathy. N Engl J Med 351: 1952-1961.

133. Strippoli GF, Craig M, Deeks JJ, Schena FP, Craig JC (2004) Effects of angiotensin converting enzyme inhibitors and angiotensin II receptor antagonists on mortality and renal outcomes in diabetic nephropathy: systematic review. BMJ 329: 828.

134. Morgensen CE, Neldam S, Tikkanen I, Oren S, Viskoper R, et al. (2000) Randomised controlled trial of dual blockade of renin-angiotensin system in patients with hypertension, microalbuminuria, and non-insulin dependent diabetes: the candesartan and lisinopril microalbuminuria (CALM) study. Brit Med J 321:1440-1444

135. Mann JF, Schmieder RE, McQueen M, Dyal L, Schumacher H, et al. (2008) Renal outcomes with telmisartan, ramipril, or both, in people at high vascular risk (the ONTARGET study): a multicentre, randomised, double-blind, controlled trial. Lancet 372: 547-553.

136. Makani H, Bangalore S, Desouza KA, Shah A, Messerli FH (2013) Efficacy and safety of dual blockade of the renin-angiotensin system: meta-analysis of randomised trials. BMJ 346: $\mathrm{f} 360$.

137. Maione A, Navaneethan SD, Graziano G, Mitchell R, Johnson D, et al. (2011) Angiotensin-converting enzyme inhibitors, angiotensin receptor blockers and combined therapy in patients withmicro- and macroalbuminuria and other cardiovascular risk factors: a systematic review of randomized controlled trials. Nephrol Dial Transplant26: 2827-2847.

138. Maione A, Nicolucci A, Craig JC, Tognoni G, Moschetta A, et al. (2007) Protocol of the long-term impact of RAS inhibition on cardiorenal outcomes (LIRICO) randomized trial. J Nephrol 20: 646-655

139. Fried LF, Duckworth W, Zhang JH, O'Connor T, Brophy M, et al. (2009) Design of combination angiotensin receptor blocker and angiotensin-converting enzyme inhibitor for treatment of diabetic nephropathy (VA NEPHRON-D). Clin J Am Soc Nephrol 4: 361-368.

140. Hollenberg NK (2010) Direct renin inhibition and the kidney. Nat Rev Nephrol 6: $49-55$ 
Citation: Iqbal S, Alam A (2013) Renal Disease in Diabetes Mellitus: Recent Studies and Potential Therapies. J Diabetes Metab S9: 006. doi:10.4172/2155-6156.S9-006

141. Uresin Y, Taylor AA, Kilo C, Tschöpe D, Santonastaso M, et al. (2007) Efficacy and safety of the direct renin inhibitor aliskiren and ramipril alone or in combination in patients with diabetes and hypertension. J Renin Angiotensin Aldosterone Syst 8: 190-198.

142. Parving HH, Persson F, Lewis JB, Lewis EJ, Hollenberg NK; AVOID Study Investigators (2008) Aliskiren combined with losartan in type 2 diabetes and nephropathy. N Engl J Med 358: 2433-2446.

143. Parving HH, Brenner BM, McMurray JJ, de Zeeuw D, Haffner SM, et al. (2012) Cardiorenal end points in a trial of aliskiren for type 2 diabetes. $\mathrm{N}$ Engl J Med 367: 2204-2213

144. Karnib HH, Ziyadeh FN (2010) The cardiorenal syndrome in diabetes mellitus. Diabetes Res Clin Pract 89: 201-208.

145. Tojo A, Asaba K, Onozato ML (2007) Suppressing renal NADPH oxidase to treat diabetic nephropathy. Expert Opin Ther Targets 11: 1011-1018.

146. Ustundag A, Tugrul A, Ustundag S, Sut N, Demirkan B (2008) The effects of spironolactone on nephron function in patients with diabetic nephropathy. Ren Fail 30: 982-991.

147. Mehdi UF, Adams-Huet B, Raskin P, Vega GL, Toto RD (2009) Addition of angiotensin receptor blockade or mineralocorticoid antagonism to maximal angiotensin-converting enzyme inhibition in diabetic nephropathy. J Am Soc Nephrol 20: 2641-2650.

148. Pitt B, Zannad F, Remme WJ, Cody R, Castaigne A, et al. (1999) The effect of spironolactone on morbidity and mortality in patients with severe heart failure. Randomized Aldactone Evaluation Study Investigators. N Engl J Med 341 709-717.

149. Pitt B, Remme W, Zannad F, Neaton J, Martinez F, et al. (2003) Eplerenone, a selective aldosterone blocker, in patients with left ventricular dysfunction after myocardial infarction. N Engl J Med 348: 1309-1321.

150. Navaneethan SD, Nigwekar SU, Sehgal AR, Strippoli GF (2009) Aldosterone antagonists for preventing the progression of chronic kidney disease: a systematic review and meta-analysis. Clin J Am Soc Nephrol 4: 542-551.

151. Ahmed MI, Ekundayo OJ, Mujib M, Campbell RC, Sanders PW, et al. (2010) Mild hyperkalemia and outcomes in chronic heart failure: a propensity matched study. Int J Cardiol 144: 383-388.

152.Bakris GL, Copley JB, Vicknair N, Sadler R, Leurgans S (1996) Calcium channel blockers versus other antihypertensive therapies on progression of NIDDM associated nephropathy. Kidney Int 50: 1641-1650.

153. Bakris GL, Weir MR, Secic M, Campbell B, Weis-McNulty A (2004) Differential effects of calcium antagonist subclasses on markers of nephropathy progression. Kidney Int 65: 1991-2002.

154.Pepine CJ, Handberg EM, Cooper-DeHoff RM, Marks RG, Kowey P, et al. (2003) A calcium antagonist vs a non-calcium antagonist hypertension treatment strategy for patients with coronary artery disease. The International Verapamil-Trandolapril Study (INVEST): a randomized controlled trial. JAMA 290: 2805-2816.

155. Dahlöf B, Sever PS, Poulter NR, Wedel H, Beevers DG, et al. (2005). Prevention of cardiovascular events with an antihypertensive regimen of amlodipine adding perindopril as required versus atenolol adding bendroflumethiazide as required, in the Anglo-Scandinavian Cardiac Outcomes Trial-Blood Pressure Lowering Arm (ASCOT-BPLA): a multicentre randomised controlled trial. Lancet 366: 895-906.

156. Ostergren J, Poulter NR, Sever PS, Dahlof B, Wedel H, et al. (2008) The Anglo-Scandinavain cardiac outcomes trial: blood pressure-lowering limb: effects in patients with type II diabetes. J Hypertens 27: 2103-2011.

157. Jamerson K, Weber MA, Bakris GL, Dahlöf B, Pitt B, et al. (2008) Benazepril plus amlodipine or hydrochlorothiazide for hypertension in high-risk patients. N Engl J Med 359: 2417-2428.

158. [No authors listed] (1998) Tight blood pressure control and risk of macrovascular and microvascular complications in type 2 diabetes: UKPDS 38. UK Prospective Diabetes Study Group. BMJ 317: 703-713.

159.Ernst ME, Moser M (2009) Use of diuretics in patients with hypertension. N Engl J Med 361: 2153-2164.

160. Bakris G, Molitch M, Hewkin A, Kipnes M, Sarafidis P, et al. (2006) Differences in glucose tolerance between fixed-dose antihypertensive drug combinations in people with metabolic syndrome. Diabetes Care 29: 2592-2597.
161. Tamura Y, Murayama T, Minami M, Yokode M, Arai H (2011) Differential effect of statins on diabetic nephropathy in db/db mice. Int J Mol Med 28: 683-687.

162. Wu Y, Wang Y, An C, Dong Z, Liu H, et al. (2012) Effects of rosuvastatin and atorvastatin on renal function: meta-analysis. Circ J 76: 1259-1266.

163. Baigent C, Landray MJ, Reith C, Emberson J, Wheeler DC, et al. (2011) The effects of lowering LDL cholesterol with simvastatin plus ezetimibe in patients with chronic kidney disease (Study of Heart and Renal Protection): a randomised placebo-controlled trial. Lancet 377: 2181-2192.

164. ACCORD Study Group, Ginsberg HN, Elam MB, Lovato LC, Crouse JR 3rd et al. (2010) Effects of combination lipid therapy in type 2 diabetes mellitus. N Engl J Med 362: 1563-1574.

165. Wanner C, Krane V, März W, Olschewski M, Mann JF, et al. (2005) Atorvastatin in patients with type 2 diabetes mellitus undergoing hemodialysis. $\mathrm{N}$ Engl J Med 353: 238-248.

166. Fellström BC, Jardine AG, Schmieder RE, Holdaas H, Bannister K, AURORA Study Group, et al. (2009). Rosuvastatin and cardiovascular events in patients undergoing hemodialysis. N Engl J Med 360: 1395-1407.

167. Holdaas H, Holme I, Schmieder RE, Jardine AG, Zannad F, et al. (2011) Rosuvastatin in diabetic hemodialysis patients. J Am Soc Nephrol 22: 13351341.

168. Colhoun HM, Betteridge DJ, Durrington PN, Hitman GA, Neil HA, et al (2004) Primary prevention of cardiovascular disease with atorvastatin in type 2 diabetes in the Collaborative Atorvastatin Diabetes Study (CARDS): multicentre randomised placebo-controlled trial. Lancet 364: 685-696.

169. Shepherd J, Kastelein JJ, Bittner V, Deedwania P, Breazna A, et al. (2008) Intensive lipid lowering with atorvastatin in patients with coronary heart disease and chronic kidney disease: the TNT (Treating to New Targets) study. J Am Coll Cardiol 51: 1448-1454.

170. Cholesterol Treatment Trialists' (CTT) Collaborators, Kearney PM, Blackwell L, Collins R, Keech A, et al. (2008) Efficacy of cholesterol-lowering therapy in 18,686 people with diabetes in 14 randomised trials of statins: a metaanalysis. Lancet 371: 117-125.

171. Desouza CV, Shivaswamy V (2010) Pioglitazone in the treatment of type 2 diabetes: safety and efficacy review. Clin Med Insights Endocrinol Diabetes 3: $43-51$.

172. Sarafidis PA, Stafylas PC, Georgianos PI, Saratzis AN, Lasaridis AN (2010) Effect of thiazolidinediones on albuminuria and proteinuria in diabetes: a metaanalysis. Am J Kidney Dis 55: 835-847.

173. Hu W, Yu Q, Zhang J, Liu D (2012) Rosiglitazone ameliorates diabetic nephropathy by reducing the expression of Chemerin and ChemR23 in the kidney of streptozotocin-induced diabetic rats. Inflammation 35: 1287-1293.

174. Nissen SE, Wolski K (2007) Effect of rosiglitazone on the risk of myocardial infarction and death from cardiovascular causes. N Engl J Med 356: 24572471.

175. Dormandy JA, Charbonnel B, Eckland DJ, Erdmann E, Massi-Benedetti M, et al. (2005) Secondary prevention of macrovascular events in patients with type 2 diabetes in the PROactive Study (PROspective pioglitAzone Clinical Trial In macroVascular Events): a randomised controlled trial. Lancet 366: 1279-1289.

176. Abdel-Rahman EM, Saadulla L, Reeves WB, Awad AS (2012) Therapeutic modalities in diabetic nephropathy: standard and emerging approaches. J Gen Intern Med 27: 458-468.

177. Barton M (2008) Reversal of proteinuric renal disease and the emerging role of endothelin. Nat Clin Pract Nephrol 4: 490-501.

178. Sasser JM, Sullivan JC, Hobbs JL, Yamamoto T, Pollock DM, et al. (2007) Endothelin $A$ receptor blockade reduces diabetic renal injury via an antiinflammatory mechanism. J Am Soc Nephrol 18: 143-154.

179. Turner NC, Morgan PJ, Haynes AC, Vidgeon-Hart M, Toseland N, et al. (1997) Elevated renal endothelin-I clearance and mRNA levels associated with albuminuria and nephropathy in non-insulin-dependent diabetes mellitus: studies in obese fa/fa Zucker rats. Clin Sci (Lond) 93: 565-571.

180. Mann JF, Green D, Jamerson K, Ruilope LM, Kuranoff SJ, et al. (2010) Avosentan for overt diabetic nephropathy. J Am Soc Nephrol 21: 527-535.

181. Thomas MC (2013) Emerging drugs for managing kidney disease in patients with diabetes. Expert Opin Emerg Drugs 18: 55-70. 
Citation: Iqbal S, Alam A (2013) Renal Disease in Diabetes Mellitus: Recent Studies and Potential Therapies. J Diabetes Metab S9: 006. doi:10.4172/2155-6156.S9-006

Page 16 of 16

182. Pergola PE, Raskin P, Toto RD, Meyer CJ, Huff JW, et al. (2011) Bardoxolone methyl and kidney function in CKD with type 2 diabetes. N Engl J Med 365: 327-336.

183. Rossing P (2013) Diabetic nephropathy: Could problems with bardoxolone methyl have been predicted? Nat Rev Nephrol 9: 128-130.

184. Soulis-Liparota T, Cooper ME, Dunlop M, Jerums G (1995) The relative roles of advanced glycation, oxidation and aldose reductase inhibition in the development of experimental diabetic nephropathy in the Sprague-Dawley rat. Diabetologia 38: 387-394.

185. Suzuki D, Toyoda M, Yamamoto N, Miyauchi M, Katoh M, et al. (2006) Relationship between the expression of advanced glycation end-products (AGE) and the receptor for AGE (RAGE) mRNA in diabetic nephropathy. Intern Med 45: 435-441.

186. Bolton WK, Cattran DC, Williams ME, Adler SG, Appel GB, et al. (2004) Randomized trial of an inhibitor of formation of advanced glycation end products in diabetic nephropathy. Am J Nephrol 24: 32-40.

187. Lewis EJ, Greene T, Spitalewiz S, Blumenthal S, Berl T, et al. (2012) Pyridorin in type 2 diabetic nephropathy. J Am Soc Nephrol 23: 131-136.

188. Levy AP (2004) Haptoglobin: a major susceptibility gene for diabetic cardiovascular disease. Isr Med Assoc J 6: 308-310.

189.Levy AP, Hochberg I, Jablonski K, Resnick HE, Lee ET, et al. (2002) Haptoglobin phenotype is an independent risk factor for cardiovascular disease in individuals with diabetes: The Strong Heart Study. J Am Coll Cardiol 40: 1984-1990

190. Milman U, Blum S, Shapira C, Aronson D, Miller-Lotan R, et al. (2008) Vitamin E supplementation reduces cardiovascular events in a subgroup of middleaged individuals with both type 2 diabetes mellitus and the haptoglobin 2-2 genotype: a prospective double-blinded clinical trial. Arterioscler Thromb Vasc Biol 28: 341-347.

191. Hartman I, Rojas E, Rodríguez-Molina D (2013) Incretin-Based Therapy for Type 2 Diabetes Mellitus: Pancreatic and Extrapancreatic Effects. Am J Ther

192. Liu WJ, Xie SH, Liu YN, Kim W, Jin HY, et al. (2012) Dipeptidyl peptidase IV inhibitor attenuates kidney injury in streptozotocin-induced diabetic rats. J Pharmacol Exp Ther 340: 248-255.

193. Hattori S (2011) Sitagliptin reduces albuminuria in patients with type 2 diabetes. Endocr J 58: 69-73.

194. Kodera R, Shikata K, Kataoka HU, Takatsuka T, Miyamoto S, et al. (2011) Glucagon-like peptide-1 receptor agonist ameliorates renal injury through its anti-inflammatory action without lowering blood glucose level in a rat model of type 1 diabetes. Diabetologia 54: 965-978.

195. Hendarto H, Inoguchi T, Maeda Y, Ikeda N, Zheng J, et al. (2012) GLP-1 analog liraglutide protects against oxidative stress and albuminuria in streptozotocin-induced diabetic rats via protein kinase A-mediated inhibition of renal $\mathrm{NAD}(\mathrm{P}) \mathrm{H}$ oxidases. Metabolism 61: 1422-1434.
196. Hanefeld M, Forst T (2010) Dapagliflozin, an SGLT2 inhibitor, for diabetes Lancet 375: 2196-2198.

197. Musso G, Gambino R, Cassader M, Pagano G (2012) A novel approach to control hyperglycemia in type 2 diabetes: sodium glucose co-transport (SGLT) inhibitors: systematic review and meta-analysis of randomized trials. Ann Med 44: 375-393.

198. Endocrinologic and Metabolic Drugs Advisory Committee Meeting (2013) FDA briefing document, canagliflozin: 4-11.

199. Karihaloo A (2012) Anti-fibrosis therapy and diabetic nephropathy. Curr Diab Rep 12: 414-422.

200. El Mesallamy HO, Ahmed HH, Bassyouni AA, Ahmed AS (2012) Clinical significance of inflammatory and fibrogenic cytokines in diabetic nephropathy. Clin Biochem 45: 646-650.

201. Adler SG, Schwartz S, Williams ME, Arauz-Pacheco C, Bolton WK, et al. (2010) Phase 1 study of anti-CTGF monoclonal antibody in patients with diabetes and microalbuminuria. Clin J Am Soc Nephrol 5: 1420-1428.

202.Zhang Z, Sun L, Wang Y, Ning G, Minto AW, et al. (2008) Renoprotective role of the vitamin $D$ receptor in diabetic nephropathy. Kidney Int 73: 163-171.

203.Pörsti IH (2008) Expanding targets of vitamin D receptor activation: downregulation of several RAS components in the kidney. Kidney Int 74 1371-1373.

204. Gunta SS, Thadhani RI, Mak RH (2013) The effect of vitamin D status on risk factors for cardiovascular disease. Nat Rev Nephrol .

205. Caprio M, Mammi C, Rosano GM (2012) Vitamin D: a novel player in endothelial function and dysfunction. Arch Med Sci 8: 4-5.

206. Sugden JA, Davies JI, Witham MD, Morris AD, Struthers AD (2008) Vitamin D improves endothelial function in patients with Type 2 diabetes mellitus and low vitamin D levels. Diabet Med 25: 320-325.

207. Kilkkinen A, Knekt P, Aro A, Rissanen H, Marniemi J, et al. (2009) Vitamin $D$ status and the risk of cardiovascular disease death. Am J Epidemiol 170: 1032-1039.

208. Witham MD, Dove FJ, Dryburgh M, Sugden JA, Morris AD, et al. (2010) The effect of different doses of vitamin $\mathrm{D}(3)$ on markers of vascular health in patients with type 2 diabetes: a randomised controlled trial. Diabetologia 53: 2112-2119.

209. de Zeeuw D, Agarwal R, Amdahl M, Audhya P, Coyne D, et al. (2010) Selective vitamin $D$ receptor activation with paricalcitol for reduction of albuminuria in patients with type 2 diabetes (VITAL study): a randomised controlled trial. Lancet 376: 1543-1551.

210. Delanaye P, Mariat C, Krzesinski JM, Cavalier E (2011). Paricalcitol for reduction of albuminuria in diabetes. Lancet 377: 635
This article was originally published in a special issue, Diabetic Nephropathy handled by Editor. Dr. Charles W. Heilig, University of Florida, USA 